\title{
Mikrobialitok jellegzetességei: a biofilmek szerepe a karbonátkiválásban
}

\author{
HiPS Kinga ${ }^{1}$, HAAs János ${ }^{1}$, SzILÁGYi Zsanett ${ }^{1,2}$ \\ 'MTA-ELTE Geológiai, Geofizikai és Ứrtudományi Kutatócsoport, 1117 Budapest, Pázmány Péter sétány 1/C \\ ${ }^{2}$ The University of Sydney, Geocoastal Research Group, 2006 NSW Camperdown, Madsen Building F09, Australia
}

\section{Characteristic features of microbialites: role of biofilms in the carbonate precipitation}

Abstract

Microbialite is a type of organosedimentary desposits where the presence of organic matrix of a microbial biofilm plays predominant role in petrogenesis. This study reviews previous researches on microbial-induced carbonate deposits, microbe-mineral interaction in carbonate precipitation, and sedimentary and petrographic features of these deposits. It also presents modern deposits and some case studies from Hungary. The activity of the bacterial biofilm communities has a significant effect on their environment and can initiate crystal nucleation and growth. The mineral precipitation can be both biologically induced and influenced wise, in contrast with biologically-controlled biomineralisation that is common in organisms with internal or external calcareous skeletons. The mineralization in the biofilms is related to the increasing alkalinity and the released $\mathrm{Ca}^{2+}$ ions, which elevates the carbonate saturation level of the pore water, or to increasing $\mathrm{pH}$ level. Previous studies showed that mineral precipitation takes places in several stages. Firstly, there is an increase in local alkalinity in the extracellular polymetric substance (EPS) that favors the formation of amorphous $\mathrm{CaCO}_{3}$ gel. Secondly, nanospheres appear in the matrix that provide substrates for mineral nucleation. Carbonate minerals that form in the realm of diagenesis have a specific petrographic features. Clotted micrite as well as the presence of calcimicrobes and fenestral pores are the microscopic components that define the microbialite. In addition to the microscopic fabric, microbialites also have various macroscopic fabric and structures that place them into four categories: laminated stromatolite, blothcy thrombolite, bush-like dendrolite, and structureless leiolite. Biofilm originated crusts can form in cavities of reef frameworks that also belong to the term of microbialite. Microbialites can compose microbial reefs or layered, stratiform sheets that are defined by the shape of the deposits and facies connections.

Keywords: microbial reef, stratiform microbialite, microbial crust, clotted micrite, calcimicrobe, fenestral pore

Összefoglalás

A mikrobialit az üledékes kőzeteknek egy olyan típusa, ahol a mikrobák alkotta biofilm szerves anyagának jelenléte meghatározó a kőzetképződési folyamatokban. A jelen tanulmány a biofilmek elmeszesedésével létrejött mészkőfajták kutatástörténetét, szedimentológiai és petrográfiai sajátosságait, továbbá a karbonátkiválási folyamatokra vonatkozó kutatásokat tekinti át, emellett bemutat egy negyedidőszaki és néhány hazai esettanulmányt. A mészvázzal nem rendelkező mikrobák élettevékenysége közvetlen környezetükre jelentős befolyással van, ami ásványkicsapódási folyamatokat indíthat el. A kristálykiválás tehát biológiai folyamatok által kiváltott vagy befolyásolt, szemben a mészvázú élőlények csoportjára jellemző kiválasztásra, ami az élőlények metabolizmusa által szabályozott biomineralizáció, azaz biológiai folyamatok által kontrollált. A biofilmekben a karbonátkiválás az alkalinitás növekedéséhez és a $\mathrm{Ca}^{2+}$ ionok felszabadulásához, azaz összességében a karbonátásványokra a pórusvíz telítettségének növekedéséhez vagy a pH növekedéséhez kapcsolható. A megfigyelések szerint az ásványkiválás több lépésben történik, azaz lokális alkalinitásnövekedés következik be a sejten kívüli polimer mártixban, majd az amorf $\mathrm{CaCO}_{3}$ gél képződését követően nanoszférák jelennek meg, amiken kristálycsírák képződnek. A diagenezis tartományában képződött karbonátásványoknak sajátos petrográfiai megjelenése van. A csomós mikrit szövet, valamint a kalcimikrobák és a fenesztrális pórusok azok a mikroszkópban megfigyelhető definitív bélyegek, amelyek alapján a mikrobialitok felismerhetők. A szabad szemmel megfigyelhetó szerkezeti jellegek alapján elkülöníthetô a lemezes sztromatolit, a foltos trombolit, a bokorszerúen elágazó dendrolit és a szerkezet nélküli leiolit. Zátonytestek elzárt üregeiben is képződhetnek biofilm eredetú kérgek, amiket szintén a mikrobialitokhoz lehet sorolni. A kőzettestek alakja és fácieskapcsolatai alapján a mikrobialitok alkothatnak mikrobazátonyokat vagy rétegkötegekből álló sztratiform lepleket. 


\section{Bevezetés}

A 20. század utolsó évtizedeiben a karbonátos kőzetek képződési viszonyainak értelmezését illetôen jelentôs hangsúlyeltolódás következett be. A korábbi évtizedekben az általános elképzelés az volt, hogy a mészüledékek döntó hányada szervezetek mészvázaiból, valamint azok aprózódásával keletkezik. Még a mésziszap (illetve az abból létrejött mikrit) képződését is elsősorban erre vezették vissza. Bár felismerték a mikrobák szerepét egyes speciális kőzetfajtáknál, például a sztromatolitok esetében (WALTER 1976), de azt kivételesnek tekintették. Az utóbbi évtizedekben azonban a szedimentológusok és a mikrobiológusok együttmúködésének köszönhetően olyan eredmények születtek, amelyek arra utalnak, hogy a mikrobák szerepe jóval általánosabb és sokkal jelentôsebb a karbonátos üledékképzôdésben és a diagenezisben is, mint azt korábban vélték. Jelen cikk a mikrobák közremúködésével folyó mészkőképződés legfontosabb elemeit tekinti át.

A mikrobialit a mészköveknek egy olyan típusa, amelyeknél a biofilm szerves anyagának jelenléte meghatározó a kőzetképződési folyamatokban (BuRnE \& MOORE 1987; STOLz 2000, 2017). A biofilm felszínhez rögzült mikroorganizmusok közössége (pl. O’ToOLE et al. 2000). Biológusok és geológusok is kutatják, hogy a mikrobák élettevékenysége milyen szerepet kap az autigén karbonátkiválási folyamatokban, de nagyon sok kérdésre még nincs egyértelmú válasz. Biomineralizációnak definiált az eukarióta élőlények mészvázának képződése, ami az élőlények metabolizmusa által szabályozott folyamat, vagyis biológiai folyamatok által meghatározott ásványkiválasztás (ADDADI \& WEINER 1992). A kutatások szerint a mészvázzal nem rendelkező mikrobák élettevékenysége közvetlen környezetükre jelentős befolyással van, ami ásványkiválási folyamatokat indukálhat. Az ily módon történô mészkiválást biológiai folyamatok által kiváltottnak vagy befolyásoltnak nevezik (DuPRAz et al. 2009, RisGAARD-PETERSEN et al. 2012). Az így létrejövő karbonátásványok sajátos szöveti megjelenést és geokémiai jellegzetességeket mutatnak (pl. BIRGEL et al. 2015). Nemcsak karbonátásványok kiválására vannak hatással a mikrobák, hanem vas-, mangán-, foszfát-, kén-, szelénásványokra, továbbá agyagásványokra is (ezeket nem tárgyaljuk).

Majdnem minden baktérium képes sejten kívüli polimer anyagot (extracellular polymeric substances, EPS) kiválasztani, amely mátrixként szolgál a biofilmekben a sejtek befogadásához (FLEMMING \& WINGENDER 2010). Az így létrejött együttmúködő mikrobaközösségekben (synergistic microconsortia) az EPS mátrixnak sajátos szerkezete van, és a mikrokörnyezet hosszú távú stabilizálásán túl még számos funkciót (sejtek védelme, tápanyagok elosztása, toxinok kiválasztása stb.) ellát (DECHO 1990, 2010; COSTERTON \& LAPPIN-SCOTT 1995). Mindezek mellett nutriensforrásul is szolgál, így mint minden más biopolimer esetében, egyes komponensei lassan bomlanak le.

Üledékes környezetekben a mikrobák alkotta biofilmek az aljzathoz, szemcsékhez vagy más élőlények felszínéhez tapadhatnak. A karbonátásványok kiválásában a prokarióta szervezeteknek, az archaeáknak és a baktériumoknak van meghatározó szerepe (pl. ALLEN et al. 2009). Ehhez a mikrokörnyezethez leginkább az algák és a gombák csoportjába tartozó szervezetek társulhatnak (RIDING 2000). A biofilmekben a karbonátkiválás és -oldódás komplex folyamatsorok eredménye és az előbbi evolúciós előnyhöz vezethetett, például az eredményesebb helyhez rögzítéssel vagy a mikrokörnyezeti paraméterek fenntartásával (MERZ-PREISS 2000). A földtörténet során és a mai környezetekben is tengerekben és tavakban képződtek/képződnek mikrobák közremúködésével jelentősebb kiterjedésú karbonátos testek, de kisebb kiterjedésben létrejöttek/létrejönnek folyóvízi, barlangi környezetekben és egyes talajokban is.

Kiemelt figyelmet érdemelnek a mikrobialitok azért is, mert a földi élet megjelenésének közvetlen dokumentumai (NUTMAN et al. 2016). A földtörténet legkorábbi szakaszait illetően, az egykori élővilág rekonstruálásánál a mai extrém környezetekben előforduló mikrobák tanulmányozásán túl, geokémiai markerekből és a mikrobialitokra vonatkozó adatokból tudunk kiindulni (DONG \& YU 2007). Kürtők, kémények, kis dómok vagy konkréciók formájában őrződtek meg azok a karbonáttestek, amelyeknek a képződése a legősibb típusú mikrobákon alapuló közösségekhez kapcsolható (pl. AgirReZabala 2009). Hasonlóakat a mai mélytengerek aljzatán és vetőzónák menti hidrotermás kiszivárgásoknál fedeztek fel (BEAUCHAMP \& Von BitTer 1992, VARGAS et al. 1998, Colín-García et al. 2016). Az elméleti földtudomány szempontjából meghatározó jelentőségú, hogy a fotoszintetizáló cianobaktériumok megjelenése az oxigén felszabadításával döntő hatással volt a Föld redox állapotára, az őslégkör átalakulására és ezáltal az élővilág további fejlődésére (EHRLICH 1998, KNOLL 2003). A legrégebbi olyan kőzet, amelyben mikrobialitok jelenlétét egyértelmúen bizonyítottnak tartják 3,45 milliárd éves és Nyugat-Ausztráliában található. A Towers Formációban sztromatolitokat találtak (Lowe 1980), és a kôzet kovásodott részeiben baktériumokra jellemző filamentumokat is megfigyeltek (AwRAMIK et al. 1983). Az archaikum valamivel fiatalabb kőzeteiben több mint 30 sztromatolitelőfordulást írtak le. A későarchaikumtól a középső-proterozoikumig (2,8-1,0 Md év) terjedő időintervallumból — amit a mikrobialitok virágkorának tekintenek — pedig a Föld számos pontjáról váltak ismertté változatos alakú és belsô szerkezetú mikrobialitok (HoFMANN 2000). Egyes típusaik árapálysíkságokon, mások sekélytengeri platformokon, ismét mások mélytengeri környezetekben képződhettek (pl. HoFFMAN 1974, GROTZINGER 1989). Bár a késő-proterozoikumban a mikrobialitok elterjedtsége és változatossága a korábbihoz képest jelentősen csökkent, a mikrobaközremúködéssel folyó karbonátképződés szerepe a fiatalabb földtörténeti szakaszokban is lényeges maradt (RIDING 2006). A fanerozoikum idején gyakran mészvázú metazoákkal együtt és esetenként önállóan is bioépítményeket, azaz zátonyokat alkottak. A mikrobaközösségek a fanerozoikumi hanyatlásuk során stresszkörnyezetekbe kiszorulva hoztak létre a prekambriumi kőzettestekhez képest csekélyebb méretú karbonátos képződményeket. 
A mikrobialitok gyakorlati jelentősége is figyelemre méltó. Egyes típusaikat a történelmi időktől kezdve építőkőként és díszítôkőként használják. Helyenként érctelepek befogadó kőzetei. Manapság azonban a mikrobák közremúködésével képződött kôzetek a szénhidrogén-kutatásban is fontossá váltak. A világ számos részén vannak olyan szénhidrogéntelepek, amelyek tárolókőzete mikrobialit, vagy olyan karbonátos kőzet, amelyek képződésében a mikrobáknak jelentős szerepük volt, és amelyeknél a képződési körülmények döntő hatással voltak a rezervoárok jellegére (WRIGHT \& RODRIGUEZ 2018).

\section{A mikrobialitok kutatásának mérföldkövei}

A mikrobák szerepét a karbonátos kőzetek képződésében néhány kutató már az 1910-es években felvetette. E koncepció úttörőjének tekinthető DREW, aki 1911-ben közölt munkájában beszámolt a mikrobaközösségeknek a karbonátkiválasztásban való közremúködésére vonatkozó megfigyeléseiről, és hangsúlyozta a mikrobák szerepének fontosságát egyes karbonátos kőzetek képződésében. Nem sokkal ezután már a laboratóriumi kísérletek is elkezdődtek, amelyek eredményei arra utaltak, hogy különböző baktériumok valóban szerepet játszanak a karbonátkiválasztásban (KELLERMAN \& SMITH 1914). Laboratóriumi vizsgálatai alapján NADSON (1928) azt is felvetette, hogy a mikrobáknak nem csupán a mészkiválasztásban, de a dolomitképződésben is lényeges szerepük lehet, bár ezt kísérletileg nem tudta igazolni.

A „Stromatolith” terminust KALKOWSKY (1908) vezette be a szakirodalomba olyan lemezes szerkezetú karbonátképződményekre, amelyeket biogén eredetűnek vélt. PIA (1926) ezeket az „Oncolith”-tal együtt nemzetségként a Spongiostromata csoportba sorolta be. Később az onkolit terminust a gumókból álló sztromatolitokra használták. PIA (1926) a Porostromata-csoportba sorolta a csôszerú, illetve csövek kötegéből felépülő meszes mikrofosszíliákat.

Az 1930-as években BLACK (1933) úttörő aktuálgeológiai kutatásai világítottak rá arra, hogy a sztromatolitok mikrobák, elsősorban „kékeszöld-algák” (mai megnevezés szerint cianobaktériumok) közremúködésével képződnek. A Bahama-szigetcsoporthoz tartozó Andros-sziget árapálysíkságát borító lemezes karbonátüledékrôl megállapította, hogy azt „kékeszöld-algák” szövedéke által stabilizált mésziszap alkotja. Azt is leírta, hogy mikroszkopikus méretû́ kerekded (coccoid) és szálszerú (fonalas) „,algákból” álló közösségekrôl van szó, ahol 15 fajt azonosított. Ezek egyfajta ragacsos anyagot hoznak létre, amely az üledékszemcsék befogására is képes (BLACK 1933).

Az 1950-es években kezdődött el a jelenkori karbonátos üledékképződési környezetek rendszeres aktuálgeológiai kutatása, és ez igen fontos szerepet játszott a karbonátszedimentológia tudományterületének létrejöttében. Ennek során az árapálysíkságok üledékképződésének részletes vizsgálatára is sor került, amelyek BLACK (1933) megfigyeléseit és következtetéseit kiegészítették, pontosították (GINSBURG
\& Lowenstam 1958; LogAn 1961; MonTy 1965, 1967; GEBELIN 1969). Árapályöv alatti zónákból a biofilmek vizsgálatával kiderítették, hogy ezek törmelékszemcséket kötnek meg (NEUMANN et al. 1970). A mikrobaközösségben MoNTy (1967) szerint a domináns „,kékeszöld-algák” mellett diatomák, zöldalgák, dinoflagelláták és baktériumok is jelen vannak. Megállapította továbbá, hogy a $\mathrm{CaCO}_{3}$-kiválasztás a fotoszintetizáló „kékeszöld-algák” aktivitásához köthető, a sejteken kívül történik, ahol mikrokristályos, nagy Mg-tartalmú kalcit képződik, amit csomós mikritnek (clotted micrite) nevezett. Más megfigyelések arra utaltak, hogy baktériumok közremúködésével is kicsapódik aragonit, kalcit és dolomit (LALOU 1957). A kutatások nyomán arra a következtetésre jutottak, hogy a mikrobák közremúködésével létrejött képződmények megnevezésére nem alkalmazható az őslénytani nevezéktan (jóllehet számos ilyen név szerepelt már akkor a szakirodalomban). LoGAN et al. (1964) a sztromatolitokra alaki jellegeiken alapuló rendszerezést javasolt. AITKEN (1967) a sztromatolithoz hasonló alakzatokat képezô, és —értelmezése szerint — mikroba közremúködéssel képződött, de lemezes belső szerkezet nélküli képződmények megnevezésére a trombolit (thrombolite) terminust vezette be. BATHURST (1971) korszakos jelentőségú kézikönyvében a sztomatolitok képződésének megismerését célzó aktuálgeológiai vizsgálatok eredményeinek átfogó összegzését adta.

A FOLK (1959) által kidolgozott, aktuálgeológiai kutatásokra és karbonátos kőzetek vékonycsiszolatos vizsgálataira alapozott szöveti rendszer, amely hosszú ideig a karbonátpetrográfiai munkák alapját képezte, a mikrobák közremúködésével létrejött kőzetek leírására kevéssé alkalmas. A rendszer azt a szemléletet tükrözi, hogy a karbonátos kőzetek uralkodó hányadát átülepített (allokém) szemcsék építik fel, amihez mikrit mátrix és vízből kémiai kicsapódással keletkezett pátkristályos cement (ortokém komponensek) társulnak. Önálló kategóriát képeztek a biolititnek nevezett autochton keletkezésú biogén vázszerkezetû kőzetek, ide sorolva a sztomatolitokat is.

A mikrokristályos kalcit, azaz a mikrit képződésének megítélése azonban kezdettől fogva viták tárgyát képezte, ahogy a mikritből álló, mikroszkopikus méretú, kerekded szöveti elemek, a peloidok képzôdésének értelmezése is. Az aktuálgeológiai megfigyelések alapján az 1970-es évek elejére az az álláspont vált általánossá, hogy a mikrit tengeri mészvázú szervezetek (elsősorban aragonitvázú zöldalgák) mechanikai aprózódásával létrejött mésziszapból keletkezik (STOCKMAN et al. 1967). Azt is megfigyelték, hogy a helyi vízáramlási viszonyok az iszap lokális felhalmozódásához vezethetnek, és eredetileg ezeket a felhalmozódásokat nevezték el iszapdomboknak (mud mound; GinsBuRG \& Lowenstam 1958). Később viszont MonTy (1967) rámutatott arra, hogy a földtörténeti múltban létrejött, uralkodóan finomkristályos karbonátból álló, egykoron az aljzatról kiemelkedést formált képződmények a jelenkori sztromatoliok esetében már dokumentált csomós mikritből állnak. Erre a szövetre a kriptalgás (cryptalgal) terminust vezette be. KRUMBEIN (1979) a homogén mikrit 
esetében azt feltételezte, hogy baktériumsejtek elmeszesedésével is képződhet.

A peloidok eredetével kapcsolatos vita is az 1960-as évek végén lángolt fel. Sokan úgy vélték, hogy iszapfaló szervezetek ürülékéról van szó (pl. MACINTYRE et al. 1968). Mások úgy vélekedtek, hogy ezek a konszolidálódott mésziszapból felszakadt apró törmelékszemcsék (JAMES et al. 1976), esetleg lehetnek még meszesedett algafonal eredetűek is (SCHROEDER 1972). Az is felmerült, hogy képződésük baktériumok tevékenységével állhat kapcsolatban (MACINTYRE \& VidETICH 1979). CHAFETZ \& FOLK (1984), CHAFETZ (1986) és CHAFETZ \& BUCZYNSKI (1992) a jelenkori tengeraljzat cementált mintáin végzett vizsgálatai olyan következtetésre vezettek, hogy a csomós mikrit (grumeux vagy grumeleuse fabric, CAYEUX 1935) képződése baktériumok életmúködéséhez köthetô. Ez utóbbiból következett, hogy a szerves anyagban kicsapódott csomós mikrit nem rokonítható a törmelékes eredetű peloidszemcsékkel.

A terminológiát illetôen az 1980-as évek lényeges fejleménye, hogy a biológusok a génsorrendre alapozott új filogenetikai rendszert dolgoztak ki, amelyben a sejtmag nélküli szervezetek, a prokarioták, így a korábban kékeszöldalgának nevezettek is, a baktériumok csoportjába kerültek (Brock et al. 1994, House et al. 2003, Oren \& Tindall 2005). Ezt követően ezeket a mikrobialitok képződésében kiemelkedő szerepet játszó szervezeteket cianobaktérium (cyanobacteria) néven említi a földtani szakirodalom is. Az 1980-as évek végére egyre több adat gyúlt össze arra vonatkozóan, hogy a karbonátos kőzetek számottevő részének képződésében a mikrobák jelentős szerepet játszanak. BURNE \& MOORE (1987) mindezen képződmények megnevezésére gyújtőfogalomként a mikrobialit (microbialite) terminus bevezetését javasolta, és ez az elnevezés rövid időn belül meg is honosodott a szakirodalomban.

Az 1980-as és '90-es évek kutatásainak egyik fontos területe a biofilm elmeszesedésének tanulmányozása volt. Ebben fontos szerep jutott az édesvízi környezetben képződött mikrobialitok vizsgálata során szerzett tapasztalatoknak is. Megállapították, hogy a biofilm meszesedését elsősorban az alkalinitás növekedése határozza meg (KRUMBEIN 1979, KNORRE \& KRUMBEIN 2000). Mások amellett érveltek, hogy a szerves anyag nukleációs felszínként szolgál, ahol a $\mathrm{Ca}^{2+}$ felszabadulása/dúsulása a lebomlási folyamatok során elősegíti a kristályképződést (pl. MoRITA 1980, DUPRAZ \& VISSCHER 2005). A kettő, azaz az anionok és a $\mathrm{Ca}^{2+}$ ionok koncentrációja együttesen adja a telítettségi indexet, ami döntő az ásványkiválás tekintetében (STUMM \& MoRGAN 1996). Az oxigéntermelő és anoxigenikus (oxigént nem termelő) fototróf szervezetek $\mathrm{CO}_{2}$-megkötése nem jár alkalinitásnövekedéssel, de a folyamat során nô a $\mathrm{pH}$, ami karbonátkiválást eredményez (PENTECOST \& RIDING 1986, MERz 1992). Azt is kimutatták, hogy a biofilm egyes részein is kialakulhat olyan alkalinitás-gradiens, amely elmeszesedést eredményez (PENTECost 1985, Beltrán et al. 2016). Bizonyos környezeti feltételek mellett azonban, pl. nagy szalinitású vagy alkáli tavakban a fototrófok $\mathrm{CO}_{2}$-felvétele nem elégséges a karbonátkiváláshoz, és az EPS $\mathrm{Ca}^{2+}$-meg- kötő kapacitása is gátolja a kristálykiválást (WESTBROEK et al. 1994; ARP et al. 1999a, b; 2001). A szerves anyag bakteriális lebontási sebességének függvényében, a pH változásának megfelelően karbonátkiválás vagy karbonátoldódás történik (BEN YAAKOv 1973, KRUMBEIN et al. 1977). A gyors lebomlási folyamatok esetében mikrokristályos karbonátkiválást figyeltek meg (VISSCHER \& STOLZ 2005), míg a kis reakciósebesség karbonátoldódáshoz vezethet (pl. CANFIELD et al. 1991, DECHO 2010). Természetes környezetben kísérleti módszerekkel elemezték a mikrobák katalitikus hatását (KANDIANIS 2007). Azt is megállapították, hogy nemcsak baktériumok, de gombák közremúködése során is történhet karbonátkiválás — ez fôleg talajokban jellemző, de sztromatolitoknál is említik (SCHMITTNER \& GIRESSE 1999, Verrecchia et al. 2003, Kolo et al. 2015). Kétségtelen, hogy az abiotikus környezeti paraméterek is lényeges hatással lehetnek a kristályképződési folyamatokra (RIVADENEYRA et al. 1985, 1994).

A következô jelentôs lépést az elmeszesedés folyamatának tanulmányozásában a biológusokkal közösen végzett vizsgálatok adták. Fluoreszcens in situ hibridizációs (FISH) és lézer megvilágítású konfokális pásztázó mikroszkópos módszert alkalmazva lehetôvé vált a mikrobaközösségek 3 dimenziós vizsgálata. Így az is megjeleníthetôvé vált, hogy egy biofilmben csapdázódott üledékes szemcsék és az autochton kiválású karbonátkristályok milyen szöveti kapcsolatban vannak a mikrobaközösséggel és az EPS mátrixszal (BAUMGARTNER et al. 2006). Ezek alátámasztották azt a korábbi felvetést, hogy bár a karbonátkiválás folyamatát sok tényezô befolyásolja, a heterotróf baktériumok kulcsszerepet játszhatnak benne (pl. CASTANIER et al. 1999, VissCHER et al. 2000). Az utóbbi évtizedben elterjedtté vált molekuláris mikrobiológiai módszer (polimeráz láncreakció, polymerase chain reaction, PCR) alkalmazásával a korábban leírtaknál számottevően nagyobb diverzitású közösségeket mutattak ki a biofilmekből, és azt is felvetették, hogy speciális mikrobaközösségek játszhatnak szerepet a karbonátkiválásban (pl. Allen et al. 2009).

Az 1990-es években a karbonátszedimentológusok érdeklődésének homlokterébe kerültek a mikrobialitok. A részletes terepi megfigyelések, a laboratóriumi kutatási módszerek fejlődése, továbbá a mikrobiológusokkal, szerves geokémikusokkal való intenzív együttmúködés eredményeként igen jelentôs volt a fejlődés a folyamatok megértését illetően. Nagyszámú részletes esettanulmány készült több témában is, egyrészt a fanerozoos mikrobazátonyokról, amiket korábban iszapdombokként írtak le (pl. JAMES \& Gravestock 1990, BeAuchamp \& SAVARd 1992, Bourque \& Boulvain 1993, Lees \& Miller 1995, Bosence \& BRIDGES 1995), másrészt a kemotróf baktériumok közremúködésével létrejött karbonátképződményekről (pl. BEAUCHAMP \& VON BITTER 1992 szerkesztette tematikus kötet). Ezek demonstrálták a mikrobák által termelt szerves anyag jelenlétében történő karbonátképződés sajátosságait és sokféleségét, továbbá új képződési modellek megalkotásához vezettek (FLAJS et al. 1995). Körvonalazódott, hogy a mikrokristályos karbonátkiválásban milyen szerep jut a 
mikrobák által kiváltott vagy befolyásolt folyamatoknak és a szerves anyag bomlásának (MONTY et al. 1995, REITNER et al. 1995, NEUWEILER et al. 2000). Az organomineralizációnak nevezett folyamatsor (TRICHET \& DEFARGE 1995, NEUWEILER et al. 2003) eredményeként a szerves anyagban kicsapódott mikrokristályos karbonátra az automikrit terminust javasolták (REITNER 1993, REITNER et al. 1995). Az ezredforduló idején RIDING (1999, 2000) foglalta össze a sztromatolitokra és a mikrobialitokra vonatkozó ismereteket. Áttekintő cikke tárgyalja a biofilmet meghatározó és ezekhez társuló szervezeteket, az EPS jelentőségét, a karbonátkiválási folyamatokat, a mikrobialitok makroszerkezeti és mikroszöveti jellegeit, valamint a mikrobialitok gyakoriságának és diverzitásának változását a földtörténet során. Ezzel egy időben jelent meg a mikrobaközremúködéssel létrejövő üledékes kőzetek jellegeit és a képződés folyamatait átfogóan bemutató RIDING \& AwRAMIK (2000) által szerkesztett tematikus cikkgyújitemény. Ezt számos hasonló tematikájú gyújteményes kötet követte (pl. KRUMBeIn et al. 2003, CAMOIN \& GAUTRET 2006, SeCKBACH \& OREN 2010, TEWARI \& SECKBACH 2011). A mikrobák közremúködésével végbemenő karbonátképződés jelentőségét és sajátos jellegét hangsúlyozva, ScHLAGER (2003) önálló karbonátképződési rendszer (carbonate factory) bevezetését javasolta: a korábban általánosan elfogadott sekélytengeri trópusi (T) és hidegvízi $(\mathrm{C})$ rendszerek mellé a mikrobás (M) rendszert, amelyet alapvetően az ,iszapdombokra” (mud mound) vonatkoztatott.

\section{Karbonátkiválás biofilmekben}

A mikrobialit kőzetek képződéséhez vezető karbonátkiválás vizsgálatának fontos állomása volt, amikor pleisztocén és holocén zátonyokból gyújtött mintákon pásztázó elektronmikroszkópos (SEM) vizsgálatokkal megállapították, hogy nagyon finom kristályokból álló csomók/rögök keletkeznek a biofilmek szerves anyagában baktériumok jelenlétében (CHAFETZ 1986). Hasonló szöveti elemeket észleltek a már nem élő cianobaktérium-szálakat burkoló szerves anyag felületén és az EPS mátrixban is (CHAFETZ \& BUCZYNSKI 1992). Az általuk vizsgált mintákban ezeknek a 20-60 um átmérôjứ csomóknak a felszínét kémiai kiválással képződött, euhedrális mikropátcement kristályai burkolták be. Fagyasztott minták SEM-vizsgálatával arra is fény derült, hogy az EPS mátrix alveoláris struktúrája határozza meg a finomkristályos csomók szöveti eloszlását (DEFARGE et al. 1996, KAZMIERCZAK et al. 1996). Az EPS mátrix vázszerkezetet ad a finomkristályok nukleációjához, majd a kristálycsomók növekedéséhez (1. ábra).

DuPRAZ et al. $(2004,2009)$ recens biofilmmel fedett és mikrobaközösséget tartalmazó üledékből vett fagyasztott mintákon tanulmányozták az elmeszesedés stádiumait, és vertikális metszetben vizsgálták az élő mikrobaközösséget az üledék felszínén és a belsejében is. Mikroszkópos és SEM-vizsgálatokkal igazolták, hogy a kristálycsírák az EPS mátrixban jönnek létre és ezt az elmeszesedés folyamata során fokozatosan helyettesíti a kicsapódott karbonát. A polimer mátrix alveoláris szerkezete és diszkontinuitása idézi elő azt, hogy a kristálycsírák csoportosulásával kristályaggregátumok (rögök/csomócskák) képződnek, amik idővel egyre nagyobbak lesznek és össze is érnek (2. ábra). Ezáltal a polimer mátrix alveoláris pórusai megőrződnek és a meszesedést követően fenesztrális pórusokként maradnak fenn (vö. DeFArGE et al. 1996, Trichet et al. 2001). A sejtkötegeket burkoló kerekded kapszula vagy hosszúkás hüvely belsejében nem észleltek kiválást, ami a sejtek savas lebomlásával magyarázható. Megállapították továbbá, hogy az élő sejteket tartalmazó kapszula/hüvely felületén sem jelentek meg kristályok. Nagy felbontású múszerekkel vizs-
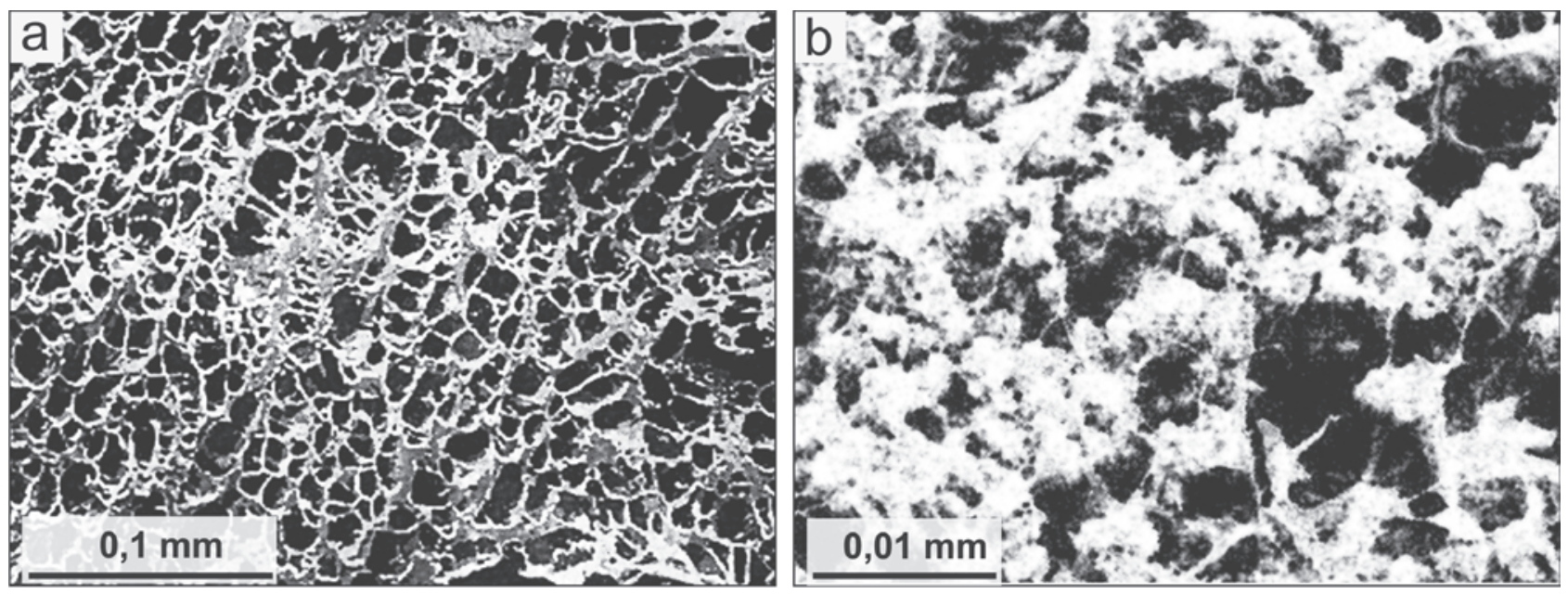

1. ábra. Biopolimer mátrix és a kicsapódott karbonátásványok szöveti kapcsolata recens sztromatolitból vett mintán (DÉFARGE et al. 1996. krio-SEM-felvétele alapján FotoScketcher programmal készített rajz) a) Sejten kívüli biopolimer mátrix (EPS) alveoláris szerkezete. b) Az EPS vázon kicsapódott, halmazokat alkotó karbonátkristályok

Figure 1. Fabric relation of biopolymer matrix and the precipitated carbonate crystals in samples from recent stromatolite (FotoSketcher drawing based on cryo-SEM images from DÉFARGE et al. 1996)

a) Alveolar structure of biopolymer matrix. b) Clusters of carbonate crystals precipitated within the EPS framework 

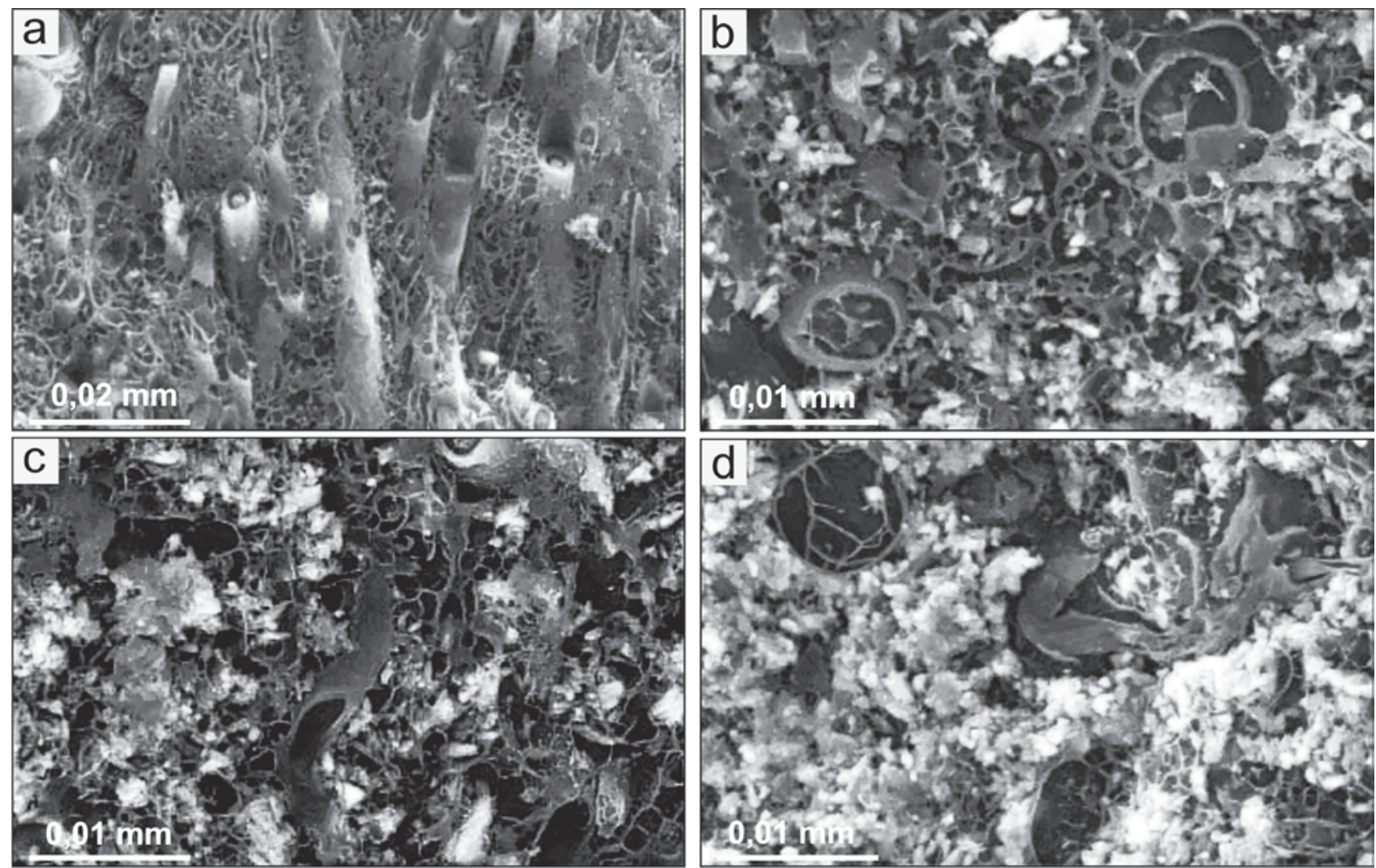

2. ábra. Biofilm elmeszesedésének stádiumai és a csomósmikrit-szövet kialakulása recens sztratiform mikrobialit több szintjéből vett mintákon (DuPRAZ et al. 2004. SEM felvétele alapján FotoSketcher programmal készített rajz). a) és c) szálas sejtek alkotta biofilm részlete, b) és d) coccoid sejtekből álló biofilm részlete a) A sejteket burkoló hüvelyek függőleges kötegekbe rendeződtek az EPS alveoláris szerkezetében. b) A coccoid sejteket burkoló kapszulák hintett elrendeződése az alveoláris szerkezetủ szerves mátrixban. A karbonátkristályok (pici fehér foltok) kis csomócskákban váltak ki a szerves mátrixban. c) és d) Az elmeszesedett lemezekben kristálycsomók vannak jelen hintetten, illetve összefüggően a mikrobialit mélyebb rétegeiben. A szerves mátrixot részben, illetve szinte teljesen helyettesítették a karbonátkristályok

Figure 2. Stages of biofilm calcification and formation of clotted micrite fabric in samples collected from several horizons of recent stratiform microbialite (FotoSketcher drawing based on SEM images from DUPRAZ et al. 2004). a) and c) Progressive calcification in filamentous-dominated community. b) and d) The same succession for coccoid-dominated community.

a) Vertical arrangement of filamentous sheats within EPS having alveolar structure. b) Biofilm with spherical sheats of coccoid cells scattered within alveolar matrix. Attached carbonate crystals (white spots) forming small clots within the organic matrix. c) and d) In the deeper horizons, scattered and densely attached carbonate clots partly or almost entirely replaced the organic matrix, respectively

gálva a kicsapódott karbonátokat azt találták, hogy ezek 200-500 nm méretú, gömbszerú (szferoid) aggregátumokból vagy kristálylapokkal határolt, 2 mm-nél kisebb egykristályokból állnak (DuPRAZ et al. 2004). Más nano- és mikroformákat is leírtak, főleg pálcika, legyező, gömb és súlyzó alakokat (BUCZYNSKi \& CHAFETZ 1991, Folk 1993, DeFARGE et al. 1996, FREYTET \& VERRECCHIA 1998).

DuPRAZ et al. (2004, 2009) a kiválási folyamat nyomon követésével kimutatta, hogy a kezdeti stádiumot követően a coccoid és fonalas baktériumok sejtjeit burkoló kapszulák és hüvelyek felületén is megjelennek a pici kristályok. Ez olyan jellegzetes formák leképezéséhez vezetett, amik megfeleltethetốek a fosszilis mészkövekből régóta ismert Porostromata-csoport képviselőivel (PRATT 1984, RIDING 1991a, KAZMIERCZAK \& KEMPE 1992, CHAFETZ \& GUIDRY 1999, STEPHENS \& Sumner 2002), azaz az egyes földtörténeti szakaszokból taxonként, különbözô nevekkel leírt formákkal, pl. Angusticellularia, Renalcis, Ortonella-Cayeuxia stb. (RIDING 2000, FLÜGEL 2004). A meszesedési folyamat későbbi stádiumában az EPS mátrix szerkezete megbomlik, miközben a szerves anyag lebomlása is előrehalad. Ezáltal nagyobb méretû́ zsugorodási pórusok is keletkezhetnek a szerves anyagban, amelyek szintén fenesztrális pórusokként őrződnek meg a kőzetekben.

Az így létrejött képződmény „szivacsszerúen” porózus vagy teljesen tömör is lehet. A következő komponensekből áll: (1) változatos nagyságú és alakú fenesztrális pórusok, (2) finomkristályos, kb. 20-50 $\mu$ m nagyságú, részlegesen vagy teljesen érintkező aggregátumok/csomók és (3) finomkristályos, belül pórusos, fonalas vagy gömbszerú szabályos/ jellegzetes formák, azaz kalcimikrobák. Ezek azok a definitív szöveti elemek, amelyek alapján az in situ kiválással a biofilmekben képződött karbonátok felismerhetők (vö. RIDING 2000). A karbonátkiválás és -oldódás folyamata az üledéklerakódást követôen a betemetődés során, azaz a diagenezis tartományában történik. A biofilmek mikrobaközössége, továbbá az üledékes környezetből átörökölt pórusvíz kémiai összetétele és paraméterei határozzák meg azokat a kapcsolt biotikus és abiotikus reakciókat, amik a karbonátkiváláshoz vezetnek (pl. VISSCHER \& STOLZ 2005). Az 
ásványok (aragonit, kalcit, nagy Mg-tartalmú kalcit, monohidrokalcit, vaterit, Ca-dolomit és hidromagnezit) a pórusvízzel egyensúlyban válnak ki, de kiválásukat az EPS-t alkotó biopolimer tulajdonságai is befolyásolják (BRAITHWAITE \& ZEDEF 1996, DuPRAZ et al. 2009).

ZAVARZIN (2002) foglalta össze az ásványkiválás lépéseit, egyszerúsítve ezek a következôk: (1) lokális alkalinitásnövekedés az EPS mártixban, (2) amorf $\mathrm{CaCO}_{3}$ gél, majd nanoszférák képződése, amiken (3) a kristálycsírák képződnek. Baradla-barlangi biofilmek vizsgálatával ENYEDI et al. (2020) is igazolták, hogy az EPS-ben jelenlévő amorf kalciumkarbonát prekurzor fontos szerepet játszik a kristályos ásványok kiválásában. A kőzetek vizsgálata során különböző geokémiai markerek alkalmazhatóak a biogén befolyás alatt kicsapódott ásványok kimutatására. Ezek közül fontosak a lipid markerek, a szén és a kén stabil izotópjainak aránya, nyomelemek (V és Cr dúsulása), a ritkaföldfémek frakciónációja és a megőrződött EPS maradványok kimutatása (pl. PAull et al. 1992, Thiel et al. 1997, Summons 2004, WebB \& Kamber 2004, DupraZ et al. 2009).

\section{A mikrobialitokat leíró szöveti rendszer}

A mikrobialitok alapvető jellegzetességeinek (üledékszerkezetek, kőzettest térbeli elterjedése és fácieskapcsolatai, mikrofáciesei és petrográfiai sajátosságai) felderítéséhez a szedimentológia és a diagenezis vizsgálati módszerei alkalmasak, amit geokémiai paraméterek mérésével lehet kiegészíteni. RiDING (1991b, 2000) az addigi ismeretanyagra alapozva összefoglalta a mikrobialitokat meghatározó szöveti elemeket és osztályozásukat. A biofilmben kicsapó- dott finomkristályos karbonát és a többnyire megjelenó fenesztrális pórusok tekinthetôk definitív bélyegeknek. Társulhatnak ezekhez a biofilmben csapdázott üledékszemcsék, vagy közbetelepülésként üledéklencsék, zsinórok, vagy lemezek, a szinszediment és a korai diagenezis során képződött cementek, ásványkiválások és pórusok (RIDING 1991b). Mindezek figyelembevételével (1) kôzettest méretû, (2) makroszkópos és (3) mikroszkópos osztályozási rendszert alakítottak ki (RIDING 2000, LEINFELDER \& SCHMID 2000, Schlager 2003). A leíró rendszerben SHIXING \& HuINENG (1992) és Riding \& SHARMA (1998) nyomán elkülönítik a kôzet komponenseinek szöveti elrendeződését (fabric), és ezen szövettípusokból létrejött szerkezetet (structure)

A mikrobialitok definitív komponensei csiszolatos mikroszkópos vizsgálatokkal azonosíthatóak. Ezek a mikritcsomók, kalcimikrobák és a fenesztrális pórusok (3. ábra). A finomkristályos elemek laza kapcsolódása jellegzetes mikroszöveti (microfabric) formákat mutat vertikálisan egymásra ránőtt kalcimikrobákkal vagy kupac- és bokorszerûen elrendeződött kristályhalmazok csoportjaival/klasztereivel (clot clusters). Az előbbire a kalcimikrobás szövet (régebbi terminus szerint porostromata), míg az utóbbira a csomós szövet (clotted fabric, régebbi szóhasználattal spongiostromata) használata terjedt el. Előfordul, többnyire vékony zsinórok formájában, szerkezet nélküli, tömör változat is (pl. MACINTYRE et al. 2000, VISSCHER et al. 2000). Azt is kimutatták, hogy a szöveti típusok változatosságát fóleg a kristályok kiválási sebessége és a szerves mátrix tafonómiai jellegei befolyásolják (3. ábra $b$; pl. TURNER et al. 2000). Mikrofáciesbesorolásuk a helyben képződött kőzettestekre alkalmazott biolitit, illetve mikrobás bound-
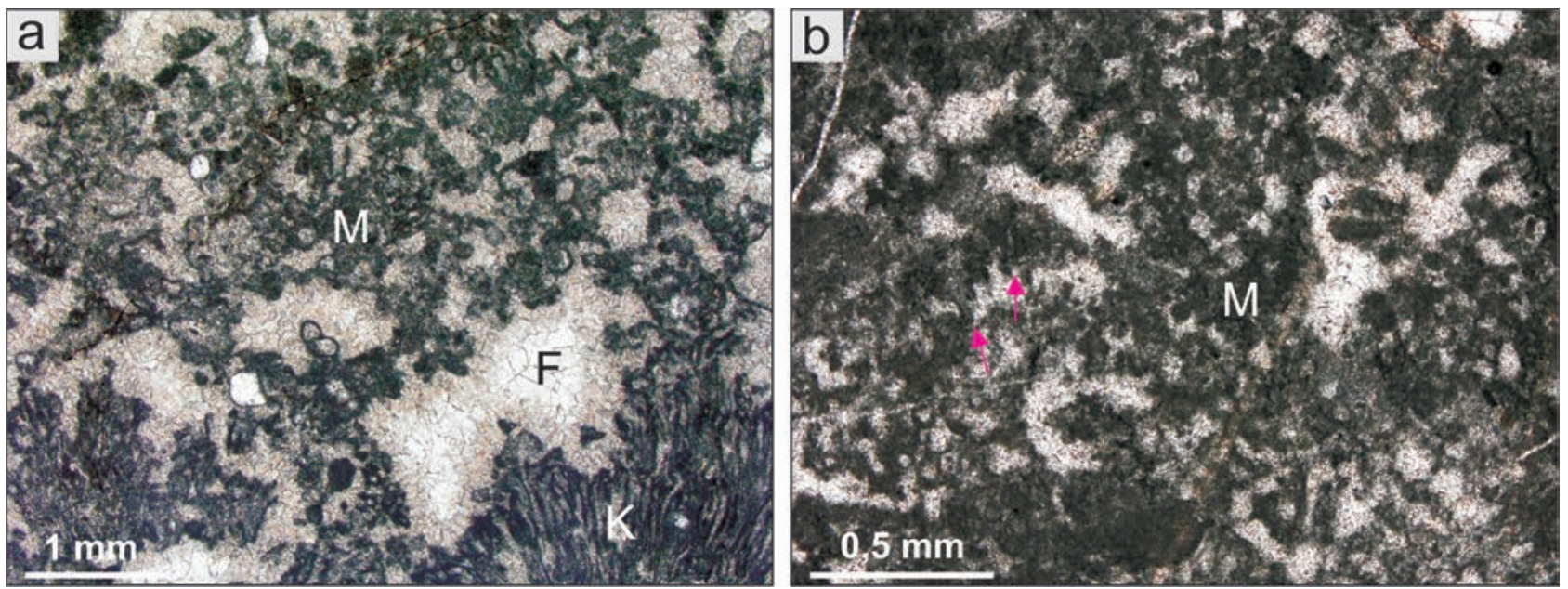

3. ábra. Mikroba boundstone jellegzetes komponensei (mikroszkópos fotók)

a) Kalcimikroba (kötegekbe rendezett szálak; $\mathrm{K}$ ), csomós mikrit (M) és változatos méretű és alakú fenesztrális pórusok (F). A pórusokat radiaxiális rostos kalcitcement tölti ki. b) Kalcimikroba rövid szálai (nyilak) vertikálisan egymás felett rendeződtek, nem alkotnak folytonos szöveti elemet, ami jelzi, hogy a szerves anyag lebomlási folyamata elörehaladottabb volt a kristályok kiválásának idején (vö. 2. ábra c). Csomós mikrit (M) halmazai felfelé szétágazó szöveti elemet formálnak köztük cementtel kitöltött fenesztrális pórusok. a) és b) Mikrobazátony, Dachsteini F. Remetehegyi T., Nézsa

Figure 3. Typical components of microbial boundstone (photomicrographs)

a) Calcimicrobe (bundles of filaments; $K$ ), clotted micrite $(M)$ and fenestral pores $(F)$ in various sizes and shapes. The pores are occluded by radiaxial fibrous calcite cement. b) Short filaments of calcimicrobes (arrows) are arranged vertically; they are dissected that indicates progressive decomposition of organic matrix during the crystal precipitation (cf. Figure 2c). Clusters of clotted micrite (M) forms upward branching elements and fenestral pores occur among them. a)-b) Microbial reef, Dachstein Fm, Remetehegy Mb, Nézsa 
stone. Szemcsevázú üledékben, ahol meghatározó a mikrobák jelenléte, a betemetődés (diagenezis) kezdeti stádiumában a szemcsék közötti biofilmekben finomkristályos cement képződik (HILLGÄRTNER et al. 2001). Az onkolit kőzetek egy fajtája — ahol az első szemcseközi cementgeneráció finomkristályos, így a kőzet onkoidos grainstone vagy onkoidos boundstone mikrofáciesú képződése szerint besorolható a mikrobialitok közé (4. ábra a). Az onkoidok olyan bekérgezett szemcsék, amelyek képződésében a mikroba biofilm meghatározó szerepet játszik. A hullámzás és árapályáramlás által mozgatott árapályöv alatti környezetben a biofilm nem tud az aljzathoz rögzülni, így homok vagy kavics méretú szemcséket burkol be, vagy csak a biofilm önmagában görgetődik az aljzaton (4. ábra b). Esetenként komplexebb, filamentumos és/vagy csomós mikrit szövetű kéreg is megjelenhet a szemcséken (4. ábra c; pl. WEBB et al. 1999). Több szemcse beburkolásával jönnek létre az aggregált szemcsék (grapestone), illetve előrehaladottabb stádiumban ezek mikrites átalakításával a „lump” szemcsék (4. ábra d). A szemcseközi finomkristályos cement elősegíti a sekélytengeri keményfelszín (hardground) kialakulását (FOLK \& LYNCH 2001).

A szabad szemmel megfigyelhető jellegeken alapuló osztályozás a kôzet komponenseinek szerkezeti elrendezô-
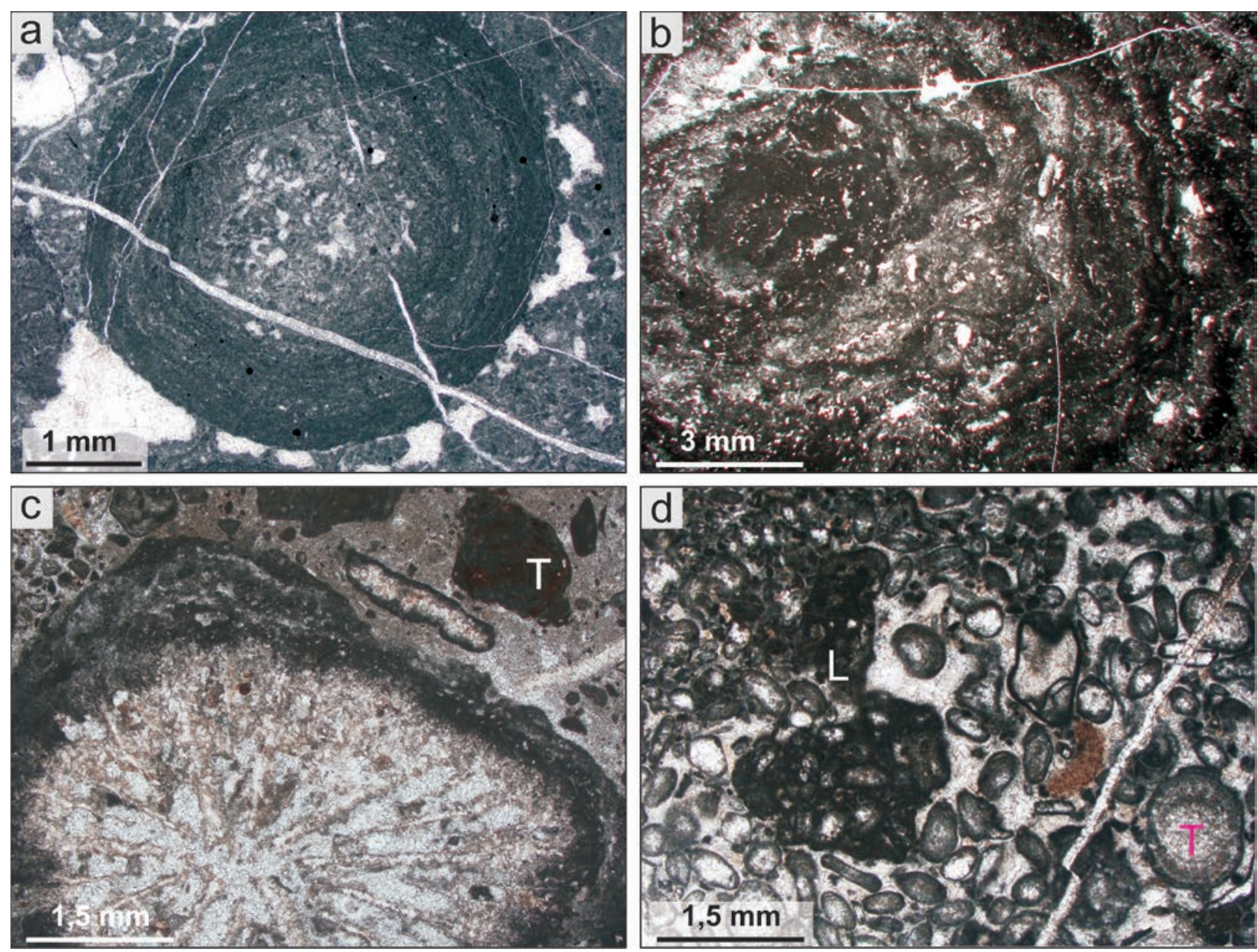

4. ábra. Mikrobák közreműködésével képződött szemcsék. a), b) és c) onkoid, d) szemcseaggregátum (mikroszkópos fotók)

a) Koncentrikus héjszerkezetủ onkoid, ahol a mag is biofilm eredetủ. Az onkoidos boundstone-ban a csemcsék közötti első cementgeneráció biofilm eredetủ csomós mikrit. Mikrobazátony, Dachsteini F. Remetehegyi T., Nézsa. b) Biofilm gomolyagból képződött onkoid, ahol tekervényes, szálas kalcimikrobák és csomós mikrit alkotják a koncentrikus héjszerkezetet. Veszprémi Márga F. Buchinvölgyi Breccsa T., Veszprém. c) Koralltöredéken tekervényes, szálas kalcimikroba és csomósmikrit-bekérgezés, illetve a bioklaszt széle mikritesedett (onkoidos-bioklasztos-peloidos wackestone). T: Tubiphytes. Sándorhegyi F. Barnagi T., Balatonfüred. d) Több szemcséböl, mikrit és csomós mikrit által összeállt szemcseaggregátumok (grapestone) és ezeknek mikritesedéssel átalakult változata („lump”; L), ahol a szemcsék között az első cementgeneráció mikrit, illetve a szövet egy része csomós mikritből és fenesztrális pórusokból áll (bal felső sarok); bioklasztos-peloidos grainstone/boundstone. A szemcseösszetétel, mikritcement és a szövet a lagúna és az árapálysíkság átmeneti zónájára jellemző. T: Triassina. Dachsteini F., Magyarpolány Mp-37 fúrás

Figure 4. Microbially formed sedimentary grains. a), b) and c) oncoids, d) aggregate grain (photomicrographs)

a) Oncoid with cortex composed by concentric laminae and the core originates from biofilm. In the boundstone, the first cement generation among the grains is clotted micrite precipitated within biofilm. Microbial reef, Dachstein Fm, Remetehegy Mb, Nézsa. b) Oncoid originates from rolled biofilm, in which curved filementous clacimicrobes and clotted micrite form the concentric cortex. Veszprém Fm, Buchinvölgy Mb, Veszprém. c) Encrustation on a coral fragment consisting of curved filamentous calcimicrobes and clotted micrite, additionally the margin of the coral fragment was micritized (oncoidal-bioclastic wackestone). T: Tubiphytes. Sándorhegy Fm, Barnag Mb, Balatonfüred. d) Aggragate grains (grapestone) consisting of several grains and micrite as well as clotted micrite, and lump grains $(L)$, which originates from micritization of grapestones. In the intergranular pores, the first cement generation is micrite, and in mottles (upper left), the clotted micrite fabric includes fenestral pores; bioclastic-peloidal grainstone/boundstone. The grain composition, the micrite cement and the fabric are characteristic for transitional zone between lagoon and tidal flat. T: Triassina. Dachstein Fm, Magyarpolány Mp-37 core 
dését veszi alapul. A lemezes szerkezetú a sztromatolit, a szabálytalan foltszerú alakzatokat tartalmazó a trombolit, a vertikális elrendeződésú, bokorszerúen elágazó alkotórészeket tartalmazó a dendrolit és a szerkezet nélküli a leiolit (5. ábra; RIDING et al. 1991, RIDING 2000, SHAPIRO 2000). Ezeken belül alosztályokat is elkülönített RIDING (2000), de a gyakorlatban ezek nem terjedtek el. A sztromatolit lemezes szerkezete leggyakrabban a csapdázott üledékszemcsék ciklusosan változó mennyiségére vezethetô vissza, így a mikrobás lemezek üledékszemcsékben gazdag lemezekkel váltakoznak. DuPRAz et al. (2006), az általuk „,biokémiai motor"-nak nevezett számítógépes szimulációval bemutatták, hogy a természetből leírt sztromatolitváltozatokat két csoportba sorolt paraméterek változtatásával létre lehet hozni. Az egyik csoport a belső faktorokat foglalja magába, vagyis a mikroba biofilm biotikus folyamatait írja le, míg a másik csoport a külső, abiotikus faktorokat, azaz a környezeti paramétereket tartalmazza. Ezek kombinációjával előállították a recens és a földtörténeti múltból ismert összes, korábban sztromatolit „taxonként” leírt, mikrobialit változatot. ANDRES \& REID (2006) és JAHNERT \& COLLINS (2013) a fenti modellt alátámasztották azzal, hogy recens sztromatolitok vizsgálatával a környezeti paraméterek és a biofilm sajátosságainak függvényében demonstrálták a morfológiai változatosságot. A mikrobialitok speciális kifejlődésének tartják a zátonyok elzárt üregeiben képződött biofilmek elmeszesedésével létrejött mikrobakérgeket is (cryptic microbial carbonates; pl. RIDING 1991b, REITNER et al. 2000, CABIOCH et al. 2006). Szabad szemmel is jól felismerhetô, nagyon jellegzetes pórustípusok társulhatnak a finomkristályos karbonátokhoz. Ilyenek a gázbuborékok formálta, közel azonos méretú és kerekded pórusok sokasága és a sztromataktisz néven emlegetett, gyakran összefüggő rendszert alkotó pórustípus (pl. REITNER et al. 2005, ZHOU \& PRATT 2019).

BATHURST (1980) sztromataktiszra vonatkozó publikációját követően PRATT (1982) összegezte és hívta fel a figyelmet arra, hogy a korábban változatos terminusokkal (pl. kriptalgás mészkő, sztromatolit, trombolit) leírt karbonáto-
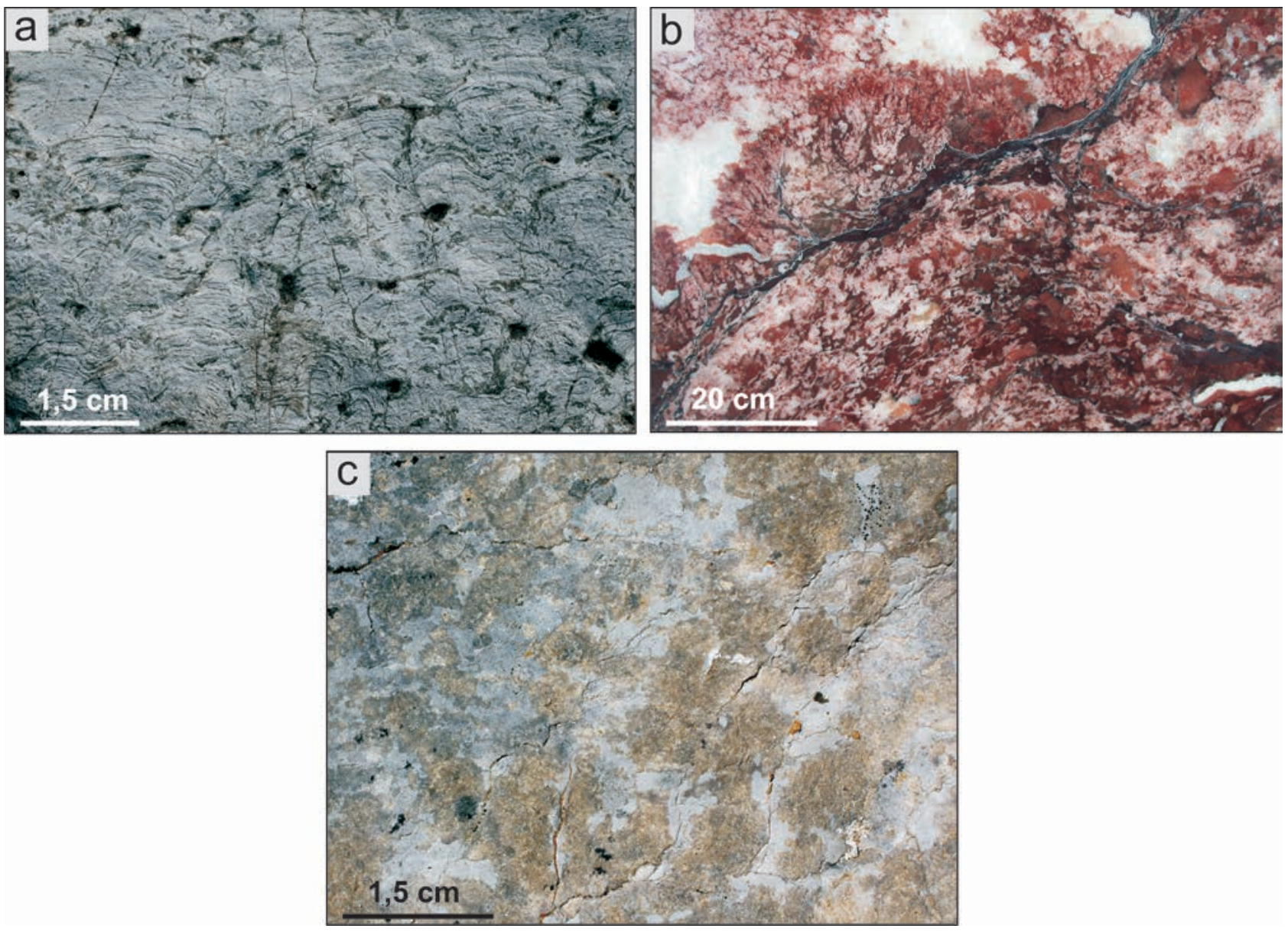

5. ábra. Mikrobialit típusai

a) Dómos felépitésủ sztromatolit hullámos lemezes szerkezete, sztratiform kőzettest, felső-triász Dolomia Principale F., Dolomitok, Passo Falzarego. b) Foltos szerkezetủ trombolit vertikálisan elágazó dendrolit részekkel, kambriumi Archaeocyatha-mikrobazátony, Dél-Spanyolország, a Göttingeni Egyetem gyüjteményében. c) Trombolit foltos megjelenése, sztratiform kőzettest, alsó-triász Kokarkuyu F., Törökország

Figure 5. Types of microbialite

a) Stromatolite showing crinkle lamination, stratiform bodv, Upper Triassic Dolomia Principale Fm, Dolomites, Passo Falzarego. b) Thrombolite showing blotchy structure with dendrolite exhibiting upward branching elements, Cambrian, Archaeocyatha-microbial reef, South Spain, from collection of Göttingen University. c) Blotchy appearance of thrombolite, stratiform body, Lower Triassic Kokarkuyu Fm, Turkey 
kat iszapdombokból (mud mound) is észlelték. Így az ilyen jellegú kőzettestek mind egy csoportba tartoznak, és megnevezésükre a mikrobazátony javasolható (FLÜGEL et al. 1993, WebB 1996, Bourque 2001, WoOd 2001). Ez a terminus alkalmazható az édesvízi mészkő (pl. PORTMAN et al. 2005) és a kemotróf biofilmekhez kapcsolt mészkő (pl. PeCKMAnN et al. 1999) egyes fáciestípusaira is. Bár a földtörténet különböző szakaszaiból a mikrobazátonyok nagyszámú előfordulását írták le (BosENCE \& BRIDGES 1995, FLAJS et al. 1995, NEUWEILER et al. 1997, LEINFELDER \& ScHMid 2000, Hips et al. 2011), a jelenkori tengerekben kevés ilyen képződmény ismert, például a Bahamákról említették (DiLl et al. 1986, Riding et al. 1991). A zátony fogalmának korábbi definíciója is átértékelődött, ma már magában foglalja a mikrobialitok egyik jellegzetes fáciestípusát is. A jelenlegi definíció szerint tehát a zátony olyan karbonátos kőzettest, mely szesszilis élőlények által jött létre és a képződés helyén in situ megőrződött, továbbá feltehetően a képződés idején topográfiai kiemelkedést alkotott (vö. RIDING 2002). A másik fáciestípushoz az árapálysíkságon képződött, rétegzett, sztratiform mikrobialitok sorolhatók. Ezek hazánkban is jól ismertek elsősorban egyes triász formációkból (Wettersteini Mészkő és Dachsteini Mészkő).

\section{Aktuálgeológiai kutatások korallzátonyokon}

A modern zátonyrendszereket felépítő korallok és algák mellett megjelenó mikrobakérgek szerepe és fontossága még ma is kevéssé ismert, jóllehet az elsődleges vázalkotók mellett jelentős mennyiségú karbonáttal járulnak hozzá a zátonyrendszerek felépítéséhez (RIDING 1991a, PERRY \& HEPBURN 2008). Legfőképpen bevonatok formájában vannak jelen, amelyek létrejöttében a biológiai folyamatok által befolyásolt mészkiválásnak, valamint az üledékszemcsék befogásának és megkötésének van meghatározó szerepe. Jelentős mértékben járulnak hozzá a zátonyszerkezet stabilitásának kialakításához (PerRY \& HEPBURN 2008, BELTRÁn et al. 2016). A nagy Mg-tartalmú kalcitból álló mikrobakérgeket a szakirodalom korábban többféle változatban is említi, úgymint mikritcement, mikrobás karbonátok, sztromatolitok és mikrobialitok (JONES \& HUNTER 1991, Riding 1991b, Montaggioni \& CAmoin 1993, CAMOIN et al. 1999, Riding \& ToMÁs 2006, Riding 2011, SEARD et al. 2011, Riding et al. 2014, BELTRÁn et al. 2016). Az indopacifikus és karibi térség negyedidőszaki zátonyrendszereiben is megfigyeltek mikrobakérgeket, amelyek általában a korallok elhalása után képződtek a zátonyok fejlődéstörténetének utolsó fázisában. A zátony elsődleges vázüregeiben vagy a zátonyok közti törmelékkel borított területeken a szemcséken bevonatként jelenhetnek meg (MontagGioni \& CAMoin 1993, CAmoin et al. 1999, BRAGA et al. 2019). A korallzátonyokon mélyített fúrások tanúsága szerint mind szerkezetileg, mind térfogatukat tekintve a zátonyok igen jelentős alkotóelemét képviselhetik. A fúrómagokban az arányuk a kőzet $80 \%$-át is elérheti (Montaggioni \& CAmoin 1993, CAmoin et al. 1999, SEARD et al. 2011, BeLtrÁN et al. 2016). Gyakran mészvázú vörösalgákkal együtt alkotnak stabil aljzatot, amely a további zátonyépítô szervezetek megtelepedését biztosítja (RIDING 1991b, BELTRÁN et al. 2016).

Korábbi kutatások kimutatták, hogy a korallzátonyokhoz társult biofilmek mikrobaközösségei valószínúleg kevésbé érzékenyek a fény és mélységbeli viszonyok változására, mint a zátonyépítő korallok. A környezetben bekövetkezett változások hatására a mikrobakérgek a zátonyszerkezeten belül vastagság- és elterjedésbeli különbségeket mutatnak (CAMoin \& MonTAgGioni 1994, Riding et al. 2014). A pleisztocén zátonyrendszerekben az elterjedésük nagyobb volt, mint a holocén sekélytengeri zátonykörnyezetekben (HEINDEL et al. 2010). Vanuatu szigetein (Óceánia) végzett kutatások alapján a 24 és 6 ezer év közötti időintervallumban észlelt nagyarányú előfordulásuk feltehetôen a nutriensgazdagabb környezethez és a gyors tengerszint-emelkedéshez köthetô (CABIOCH et al. 2006). Az Atlanti-, az Indiai- és a Csendes-óceán területén (Tahiti, Belize és Maldív-szigetek) végzett kutatások szerint jelentôsebb elterjedésük a vulkáni kőzetek mállásához köthetô nutriensgazdagsággal hozható kapcsolatba. A vulkáni alapkőzetre épült zátonyegyüttesekben vastagabb mikrobaréteget figyeltek meg, és ezt a vulkáni kőzetek mállása során felszabaduló foszfor, magnézium, kalcium és vas tengervízbe kerülésének tulajdonították (HeINDEL et al. 2009, 2010, 2012).

WEBB \& KAMBER (2000) szerint a mikrobialitok ritkaföldfém (RFF) tartalma megbízható információt nyújt az óceánok egykori oxidációs állapotáról, a szárazföldi törmelékbeszállításról és a felhalmozódási környezetről, tehát az őskörnyezet jelzőjének tekinthető (paleoproxi). RIDING et al. (2014) vizsgálatai alapján a mikrobakérgek vastagsága függ a pH-tól, a tengervíz karbonáttelítettségi szintjétól és a zátony vázszerkezetében létrejött vázüregek nagyságától, de leginkább a vízkémiai változásoktól. Megfigyeléseik szerint vastagabb kérgek jelentek meg a korallzátonyokon a glaciális és az azt követő átmeneti időszakokban, mivel akkor a karbonáttelítettségi szint magasabb volt, és a felszíni tengervíz lúgosabb lehetett. Ezzel ellentétben magasabb tengervízszint idején, leginkább az interglaciális szakaszokban vékonyabb kéreg képződött a savasabb környezet és az alacsonyabb karbonáttelítettségi szint miatt. Összességében, ezen modell szerint a mikrobialitok érzékenyek az óceánban bekövetkező vízkémiai változásokra és pH-paleoproxiként is alkalmazhatóak az egykori savasodási periódusok kimutatására.

\section{Mikrobakérgek tér-és idóbeli elterjedése az elmúlt 30 ezer évben:}

esettanulmány a Nagy-korallzátonyon, Ausztrália

A Nemzetközi Mélytengeri Fúrási Program (IODP) 325. expedíciójának 2010-ben mélyített fúrásai igen nagyszámú adatot szolgáltattak a Nagy-korallzátony elmúlt 30 ezer éves fejlődéséről. A fúrások a zátonyperem három helyszínén (Hydrographer's átjáró, Noggin-hát és Ribbon-zátony) mélyültek (6. ábra). A kutatás fô célja a tengerfelszín vízhő- 


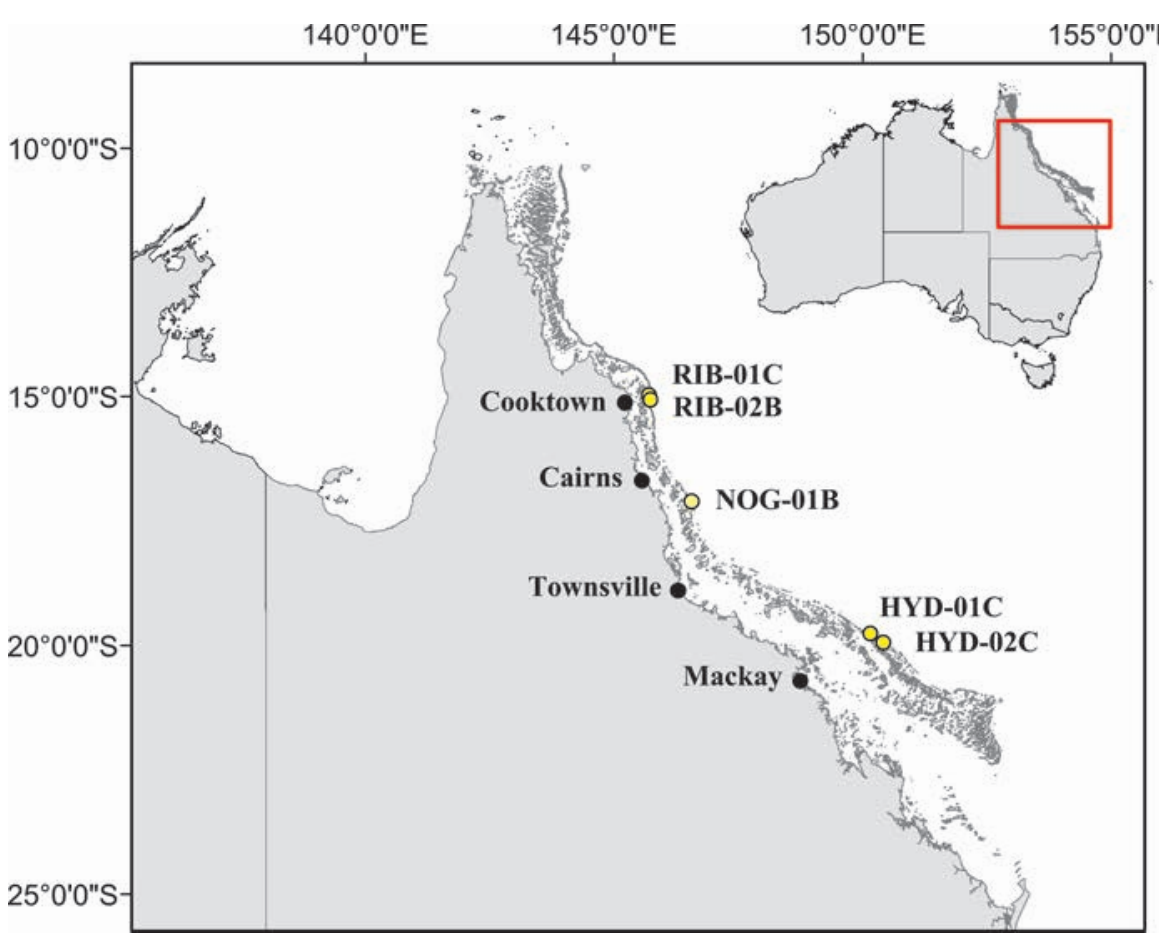

6. ábra. A Nemzetközi Mélytengeri Fúrási Program (IODP) 325. expedíciójának helyszínei (WEBSTER et al 2011). RIB-01C és RIB-02B: Ribbon-zátony (Cooktown part mentén); NOG-01B: Noggin-hát (Cairns part mentén); HYD-01C és -02C: Hydrographer's átjáró (Mackay part mentén)

Figure 6. Integrated Ocean Drilling Program (IODP) Expedition 325, Great Barrier Reef, Australia, transects location (WEBSTER et al. 2011). RIB-01C and 02B: Ribbon Reef (Offshore Cooktown); NOG-01B: Noggin Pass (Offshore Cairns); HYD-01C and 02C: Hydrographer's Passage (Offshore Mackay)

mérsékletének és a tengervízszint változásának rekonstrukciója az utolsó glaciális maximum (UGM) és az azt követő átmeneti időszak idején, továbbá ezeknek és egyéb környezeti változások hatásának nyomozása a Nagy-korallzátony fejlődésére. A rekonstrukciók során 30 és 9 ezer év között 5 fó zátonyépülési szakaszt azonosítottak (WEBSTER et al. 2011, 2018; YокоYAMA et al. 2011, 2018). A fúrómagokból 6 különböző korallegyüttest dokumentáltak (WEBSTER et al. 2018, HumBLET et al. 2019), és mind a zátonyon (reefal), mind a zátonyelőtérben (fore-reef) mikrobakérgeket írtak le (BRAGA et al. 2019). Keletkezésüket az UGM és korai átmeneti időszakban megtelepült biofilmek anoxikus környezetben előforduló szulfátredukáló baktériumok aktivitásához kötötték. Előfordulásuk szerint a mikrobakérgek két típusát különböztették meg: (1) a zátonytest vázüregeiben létrejött és (2) a zátonyelőtér aljzatán bioklasztok és bekérgezô korallok által létrehozott üregekben képződött kérgeket (BRAGA et al. 2019).

SZILÁGYI et al. (2020) a fúrómagok (NOG-01B és HYD01C) feldolgozásánál 2D és 3D technikát alkalmazva kerestek összefüggéseket a mikrobakérgek tér- és időbeli elterjedése és a környezeti paraméterek között. Az eredmények globális kiterjesztéséhez figyelembe vették az azonos idôintervallumból származó, 17 egyéb zátonyegyüttesből korábban leírt mikrobakérgeket is. Fúrómagrészletekről készült CT-felvételeken az AVIZO szoftver segítségével 3D-ben elemezték a mikrobakérgek elterjedését és térfogatát (7. bakérgek vastagságának változásában: az UGM csúcspontjáig a vastagság növekedése, majd az átmeneti időszakban és a holocén idején csökkenése jellemző. A vastagságadatok összevetése a környezeti paraméterek, azaz a felszíni tengervíz hőmérséklet, tengervízszint, nutriensellátottság, üledékbeszállítás, vízkémiai jellegek változásával rávilágítottak a mikrobakérgek növekedését befolyásoló tényezőkre. Az adatok leginkább a vízkémiában bekövetkező változásokkal, úgy mint a csökkenő pH és karbonáttelítettségi szinttel, illetve a növekvő parciális $\mathrm{CO}_{2}$ szinttel mutattak korrelációt. Ezek alapján megállapítható volt, hogy az egyéb környezeti paraméterekkel való lineáris korreláció hiánya miatt a mikrobakérgek növekedésére leginkább a vízkémiai változások voltak hatással.

\section{Mikrobialitok a hazai földtani képzódményekben}

A földtani kutatások során számos hazai képződményben figyeltek meg a mikrobialit kategóriába sorolható kőzetfajtákat. A kőzetek jellegeit ismertető leírások elsősorban sztromatolitok és onkoidok jelenlétét említik. A makroszkópos megfigyeléseket sok esetben mikroszkópos vizsgálatok is kiegészítették, de a mikrobialitok részletes vizsgálatára és a képződési viszonyok pontosabb tisztázását célzó értelmezésére jóval kevesebb esetben került sor. 

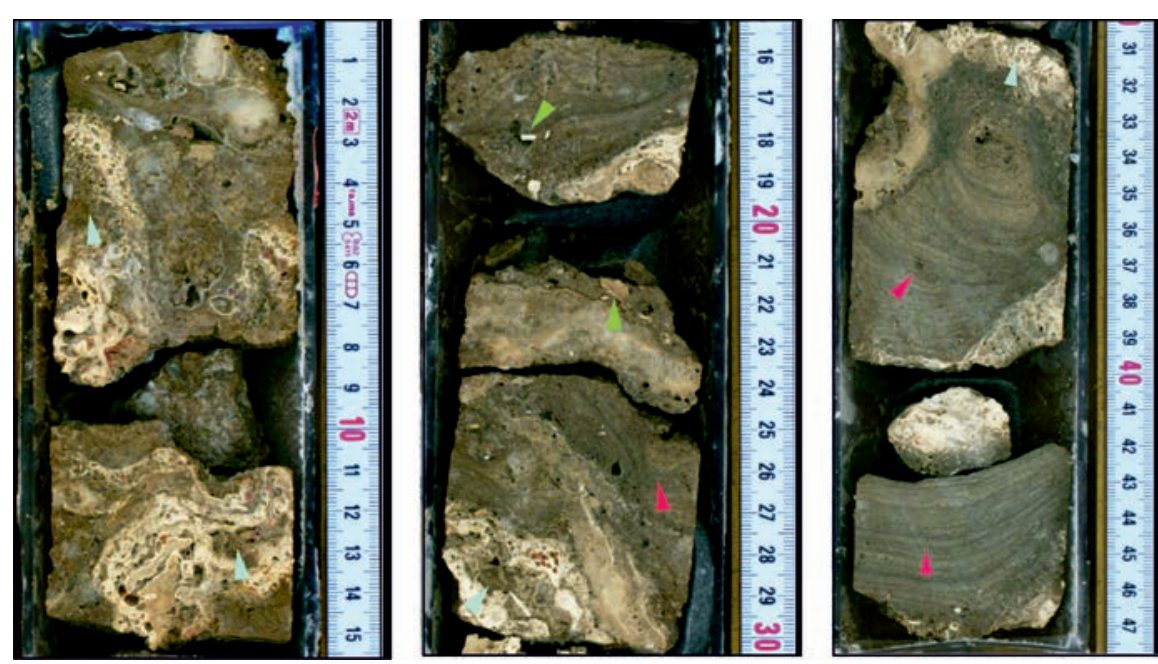

7. ábra. Reprezentatív zátony fúrómag, az IODP Exp. 325. NOG-01B helyszín, 54B lyuk, 4. fúrása (M00054B4R1; forrás: IODP Exp. 325 Core Depository Proceedings; WEBSTER et al. 2011). A mag a tengervízszint alatt 125,33-125,81 m közötti szakaszból származik. BRAGA et al. (2019) által leírt néhány zátonyon megjelenó mikrobialit típus azonosítható benne. Kék nyíl jelzi az üregeket kitöltő, piros a lemezes és réteges mikrobialitot, míg a zöld nyíl a mikrobakéreg által bevont törmeléket

Figure 7. A representative reef core section from the IODP Exp. 325 NOG-01B transect, hole 54B, run 4 (M00054B4R1; source: IODP Exp. 325 Core Depository Proceedings; WEBSTER et al. 2011). The core extends from 125.33 to 125.81 meter below sea level ( $\mathrm{mbsl}$ ). Three types of reefal microbialites can be identified by using the description of BRAGA et al. (2019). Reef framework pore-filling microbialite (blue arrowhead), laminated microbialite (red arrowhead), and microbial coated debris (green arrowhead)

Az alábbiakban rövid áttekintést adunk a mikrobialitok fontosabb hazai előfordulásairól, majd néhány esettanulmányt mutatunk be a részletesebben vizsgált triász sztromatolitokról, valamint az utóbbi évtizedben hazánkban is felismert és vizsgált mikrobazátonyokról.

\section{Sztromatolit- és onkoidelófordulások}

Hazánkban ismert legidősebb sztromatolit-előfordulásnak a Polgárdi melletti Szárhegy kőfejtőjében feltárt, devonba sorolt Polgárdi Mészkő tekinthetô. A kisfokú metamorfózist szenvedett vastagpados mészkő okkersárga lemezes és világosszürke rétegek váltakozásából áll. A lemezes szerkezetû padok makroszkópos jellegei és csiszolatos vizsgálatai is sztromatolitra utalnak, de a metamorfózis a szöveti jellegek egyértelmú azonosítását nem teszi lehetôvé (FÜLÖP 1990).

Számos triász időszaki karbonátos kőzetből írtak le mikrobiolitot. Nemzetközi viszonylatban is kiemelkedő jelentôségú a Bükkben ismertté vált, a perm-triász határán lezajlott globális környezeti krízist követôen létrejött sztromatolit, ezért vizsgálatának eredményeit lentebb részletesebben tárgyaljuk. A középső- és a késő-triász karbonátplatformok és rámpák belsô, védett részén a tengerszint oszcillációja következtében periodikusan biofilmmel borított árapálysíkságok alakultak ki, ami sztromatolitpadok képződését eredményezte. Ilyen előfordulások ismertek a Bükk (VELLEDITS et al. 1999, 2004), az Aggteleki-karszt (PIROS 2002, KovÁcs et al. 2004) és a Dunántúli-középhegység (HAAs et al. 2004), valamint a Mecsek és a Villányi-hegység területén (TÖRÖK 1997, 1998; BÉRCZINÉ MAKK et al. 2004;
LUKOCZKI et al. 2020). A Keszthelyi-hegység környékén a karni Edericsi Mészkő több mint $100 \mathrm{~m}$ vastagságú onkoidos grainstone kifejlődése ismert (GócZÁn et al. 1993). Az Aggteleki-karszton a szintén karni korú Hallstatti Mészkô Szádvárborsai Tagozatában ismert onkoidos mészkő képződése a Wettersteini karbonátplatform lezökkenéséhez és karbonátplató kialakulásához köthető, amit az onkoidok magjában is megjelenó brachiopodák jeleznek (KovÁcs et al. 1993). A mecseki felsô-anisusi Kozári Mészkő́ben kagyló- és csigahéjak mikrobás bekérgezésével létrejött, több centiméteres onkoidok tömegét tartalmazó padok figyelhetôk meg (TöRÖK 1997).

A Bakonyban a Dachsteini Mészkô fedôjét képezô hettangi, sekélytengeri Kardosréti Mészkő egyes rétegei uralkodóan 3-5 mm, de olykor 1-1,5 cm átmérôjű onkoidszemcsékből állnak (HAAs et al. 1984, VöRÖS \& GALÁCZ 1998). A Dunántúli-középhegység északkeleti részén nyomozható, hogy a Dachsteini platform megfulladását követôen a jura sekély pelágikus karbonátüledékek lerakódása csak a hettangi késői szakaszában indult meg (Tata környéke). A rétegsor több centiméteres onkoidokat, mikrobabekérgezéses ammoniteszeket tartalmazó paddal kezdődik (FÜLÖP 1975, HAAS \& BUDAI 1995).

A Villányi-hegység üledékhézagokkal tagolt jura rétegsorában, a pliensbachi rétegeket lezáró keményfelszín fölött kondenzált (néhány deciméter vastagságú), drapp-sárgasötétvörös színú, bath-callovi mészkőrétegek települnek (VÖRÖS 1972, 2010). Az 1960-as években lengyel kutatók ismerték fel és írták le, hogy e háromosztatú rétegcsoport középső részén $5 \mathrm{~cm}$ vastag sztromatolitréteg figyelhető meg. A sztromatolit alatt és felett a mészkő mikrit alapanyagába 5-10 cm átmérôjű onkoidok ágyazódnak, melyek magját többnyire ammoniteszek vagy belemnitesz rosztrumok képezik (RADWAŃSKY \& SZULCZEWSKI 1965, 1966). A későbbi vizsgálatok azt is megállapították, hogy ezek nem karbonátonkoidok, hanem vasásványokból állnak, valamint foraminifera és más mészvázú taxonok is társulnak a filamentumokhoz (GRADZIŃSKI et al. 2004). Ez utóbbi kutatásokkal összhangban VöRös (2010) szerint a vasas mikrobakérgeket és az onkoidokat nem fototróf szervezetek, hanem valamilyen más mikroorganizmusok hozhatták létre. Tata környékén a felső-jura-alsó-kréta rétegek egyenlőtlen felszínére jelentős üledékhézaggal települt Tatai Mészkô bázisán max. $20 \mathrm{~cm}$ vastag foszforitsztromatolit és onkoidok is találhatóak (FÜLÖP 1975, SzIVES et al. 2007).

A Villányi-hegységben az alsó-kréta Nagyharsányi 
Mészkő legalsó részén tavi, árapálysíksági, majd sekélytengeri környezetben létrejött kőzetek ciklusos váltakozásából álló rétegsor figyelhető meg. Az árapálysíkságon keletkezett rétegcsoport jellemzően feketedett litoklasztokat is tartalmazó breccsával indul, amelyre néhány deciméter vastagságú, sík vagy enyhén hullámos sztromatolitrétegek települnek (CSÁSZÁR 2002).

\section{Mélyebb rámpakörnyezetben keletkezett sztromatolit a triász bázisán a \\ Bükki-parautochton rétegsorában}

A Tethys nyugati elvégződésében kialakult széles, sekély selfet a perm végén karbonátos üledékek borították. A kihalási eseményt követôen - amit a rétegsorban a kb. 1 m vastag meszes aleurolitréteg képvisel - a finomszemcsés karbonátos üledékképződés folytatódott (HAAs et al. 2007). RIDING \& LIANG (2005) tanulmánya szerint a fanerozoikum során a nagyobb kihalási eseményeket követően elterjedtté váltak a mikrobialitok, amit alapvetően a metazoák hiánya és a tengervíz telítettségi szintjének növekedése idézhetett elô. A bükki triász rétegsor bázisán a $0,5 \mathrm{~m}$ vastag, vékony réteges, bioturbált mudstone felett egy kb. 8 m vastag síklemezes sztromatolitszakasz települ (8. ábra; HIPS \& HAAS 2006). A leggyakoribb mikrofácies-komponensek a finomkristályos mikritbe ágyazott, üreges belsejű, gömbszerû elemek halmaza, a csomós mikrit, a rétegzéssel párhuzamosan rendeződött filamentumok kötegei és a peloidok. Mindezek a komponensek az aljzatot beborító biofilm elmeszesedésével jöhettek létre, a peloidok pedig az elmeszesedést követően felszakadt és áthalmozott szemcsék. A síklemezes szerkezet egyrészt az elmeszesedett biofilmekből, másrészt az ezek épülését megszakító, áthalmozott detritális szemcsékben gazdag üledékes réteglemezek váltakozásával jött létre. A sztromatolit belső mikroszövete alapján egyszerú és komplexebb összetételû, vagyis különbözô fejlettségú biofilmek feltételezhetőek. A fáciesek korrelációja alapján a sztromatolit az árapályöv alatti zónában, a viharbázis környékén keletkezhetett. A perm végi kihalás nyomait megôrzött szakaszok felett települő mikrobialitrétegek számos tethysi szelvényből ismertek (XIE \& KERSHAW 2012). Az elterjedt mikrobialitok mellett a geokémiai markerekben kimutatott eltolódások alátámasztják azt a feltételezést, hogy a perm végén és a kora-triászban jelentősebb változás történt a tengervíz kémiai paramétereiben.

A Dachsteini platform árapálysíkságán képződött mikrobialitok a Dunántúli-középhegységben

A késô-karni idején a Neotethys-óceán rendkívül széles és topográfiailag kiegyenlített peremvidékén hatalmas kiterjedésû karbonátplatform-rendszer alakult ki. A Dunántúliközéphegységi szerkezeti egység a Neotethys passzív peremének egy szegmensét képezte, északkeleti része a platformmedencékkel tagolt külső részéhez, míg középső és délnyugati része védett belső övezetéhez tartozott (HAAS et al. 1995, HAAs \& BUdAI 1995, HAAs 2002). Az utóbbi övezetben 2,5-3 km vastagságú, ciklusos felépítésú, karbonátos kőzetekből álló rétegsor képződött (HAAs 1988). A tengerszint

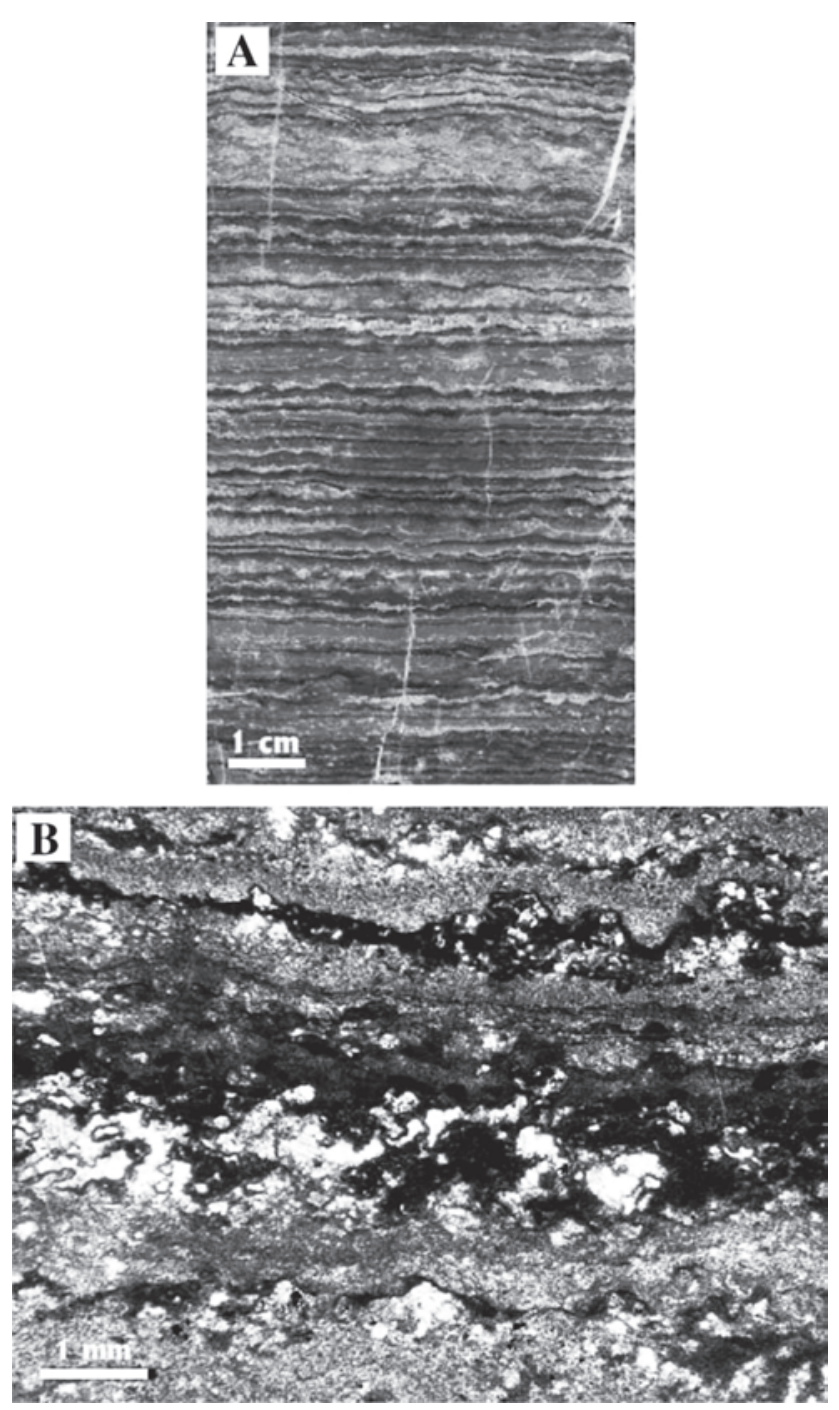

8. ábra. Síklemezes sztromatolit. Gerennavári F., Bálvány K-i szelvény (HIPS \& HAAs 2006)

A) Finoman redőzött lemezesség. B) A jellegzetes mikroszerkezetet az elmeszesedett biofilm lemezek (sűrű és csomós mikrit fenesztrális pórusokkal) és a detritális lemezek váltakozása adja. Mikroszkópos fotó

Figure 8. Stromatolite with planar lamination. Gerennavár Fm, section Bálvány E (HIPS \& HAAS 2006)

A) Crinkle lamination. B) Typical structure is formed by alternation of calcified biofilm (dense and clotted micrite with fenestral pores) and lighter detrital laminae. Photomicrograph

periodikus oszcillációja következtében létrejött eróziós felszínekkel határolt, méter nagyságrendû peritidális ciklusok az árapálysíkági és a sekély árapályöv alatti környezetben létrejött kőzetfajtákból állnak. Az összlet alsóbb része (felsôkarni-középső-nori Fődolomit Formáció) közvetlenül a lerakódás után dolomitosodott. Ebben a szemiarid klímának lehetett meghatározó szerepe (BALOG et al. 1999; HAAS et al. 2012, 2015). A középső-nori késôi szakaszában a klíma fokozatosan humidabbá válása részleges dolomitosodást eredményezett, majd lényegében megszúnt (középső-norirhaeti Dachsteini Formáció). Így a cikluson belül a záró rétegtagok jellegei megváltoztak, a dolomitosodást a kalkrétképződés váltotta fel.

A karbonátplatformok belső övezetében létrejött ciklu- 
soknak a Dachsteini Mészkőből leírt típusát FiSCHER (1964) nyomán Lofer-ciklusnak nevezik. A sztromatolit, ami a Btagként jelölt fácies (FISCHER 1964), a ciklusok árapálysíkságon képződött egysége. A Fődolomit esetében a sztromatolitszakaszok vastagsága gyakran a ciklus teljes vastagságának a felét is eléri, és olykor meg is haladhatja azt. Megjelennek a ciklusok bázisán, de a ciklusok felsô részén is (HAAs 2004). Nem csak sík lemezes lehet, ritkábban néhány milliméteres-centiméteres dómos szerkezetet is formálhatnak. Száradási repedések gyakoriak, ritkábban indián sátorhoz (teepee) hasonlító alakzatot formáló szerkezetek figyelhetôk meg (HAAs et al. 2015). A sztromatolitpadok felsố részén gyakori a breccsásodás, és sztromatolit-litoklasztok gyakran a sztromatolitpad fölötti, árapályöv alatti sekélytengeri eredetú réteg alsóbb részén is megjelennek. A sztromatolitpadokat jellemzően finomkristályos karbonát, csomós mikrit, valamint a rétegzéssel párhuzamosan rendezódött, néhány milliméteres vagy annál kisebb átmérôjuu, belső üledékkel és cementtel kitöltött fenesztrális pórusok alkotják (HAAs et al. 2015).

A Lofer-ciklusos Dachsteini Mészkő esetében a mikrobialitpadok (B-tag) a meteorikus diagenezis során képződött vöröses vagy zöldes színú agyagos kalkrét breccsásodott rétegei (A-tag) felett jelennek meg a ciklus alsó részén vagy olykor a ciklus legfelső egységeként is (HAAs 1991). A mikrobialitpadok vastagsága a formáció alsóbb részén több deciméter, de esetenként az egy métert is meghaladja. A formáció felsőbb részén azonban többnyire csupán 1-2 deciméter. A mikrobialitrétegek szürkésfehér, halványszürke színúek, olykor sárgás vagy rózsaszínes árnyalattal, ez utóbbit a biofilmben csapdázódott, eolikusan szállított karbonátszilt adja (9. ábra). Szöveti jellegeik alapvetően megegyeznek a Fődolomit Formációnál leírttal. Csomós mikrit szövet gyakori az árapálysíksági és a bioklasztos lagúna litofáciesek átmeneti zónájában (9. ábra). Ritkán mikropátcementtel kitöltött finomkristályos, szálas szöveti elemeket, kalcimikrobákat is meg lehetett figyelni (HAAs 2004). A fenesztrális pórusokat általában kalcitcement tölti ki, de a formáció részlegesen dolomitosodott alsó tagozatában a pórusok falát apró dolomitkristályok szegélyezik, míg belsejüket kalcitpát tölti ki. Gyakori a pórussorok egyesülése, ezáltal rétegzéssel párhuzamos lemezrepedések kialakulása, amelyeket részben belsô üledék, részben kalcitcement tölt ki (HAAS 2004). A mikrobialitpadok felsô részén gyakoriak a száradási repedések és a száradáshoz, illetve kalkrétképződéshez köthetô breccsásodás, továbbá az így képződött litoklasztok átülepítés utáni beágyazódása is sok esetben megfigyelhetô a közvetlen fedő sekélytengei pad (C-tag) alsó részén (HAAs 2004).

\section{Mikrobazátonyok, sajátos sztromataktisz. elófordulások és édesvízi mikrobialit kôzettestek}

A jelenleg használt terminusrendszer alapján hazánk területén néhány mikrobazátony és szivacs-mikrobazátony ismert. Ezek közül a legidôsebb karbon korú, és a Bükkben fordul elő. A Mályinkai Formáció Berenási Tagozatában palába települt mészkôtestek több szintben nagy méretú lencsesorokat képeznek (FÜLÖP 1994). A Csikorgónál feltárt lencsékben a Chaetetes-féle szivacsok csomós mikrit
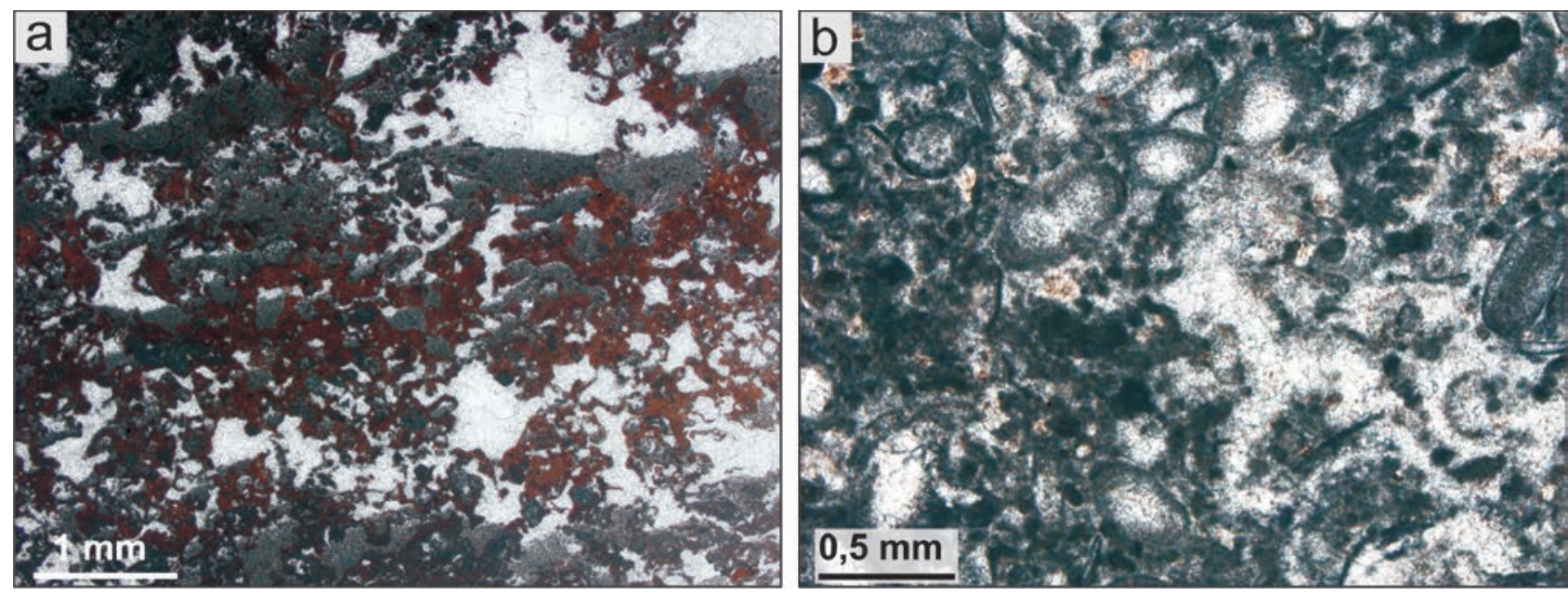

9. ábra. Az árapálysíkság különböző zónáiban képződött, eltérő típusú mikrobás boundstone a Dachsteini Mészkőből (mikroszkópos fotók)

a) Hintetten csomós mikrit (sötétszürke foltok) között változó méretű fenesztrális pórusok, amiket geopetális szerkezetben belső üledék (középszürke) és kalcitpát cement (fehér) tölt ki. A detritális eredetű, eolikusan szállítódott karbonátszilt (vörös) a biofilmben csapdázódott, és így a csomós mikrit komponenshez kötődik a szövetben. A nagyobb fenesztrális pórusokra jellemző a felfelé csúcsosodó és elágazó alakzat, ami a szerves anyag lebomlása során keletkező gázok eltávozásával jöhetett létre. Képződése az árapályzóna felsỏ részén volt. Porva Po-89 fúrás. b) Mikritcsomók kis klasztereket alkotnak, ahol a csomók részlegesen összeérnek. Ebbe a szövetbe ágyazódnak foraminiferák és más bioklasztok, köztük kalcitcement kitöltésủ fenesztrális pórusok. Képződése az árapálysíkság és a lagúna határán volt, a bioklasztok a hullámzással és az árapályáramlással áthalmozódtak és a biofilmbe beágyazódtak. Magyarpolány Mp-37 fúrás

Figure 9. Various microbial boundstone, which were formed in different zones of tidal flat, Dachstein Fm (photomicrographs)

a) Fabric is composed by clotted micrite (dark grey), fenestral pores in various sizes, occluded by internal sediment (grey), and clacite spar cement (white). Detrital carbonate silt (reddish) was eolian transported and trapped in biofilm, thus it is related to clotted micrite. Conical form of larger fenestral pores was likely formed by escaping gas bubbles that was originated from decomposition of organic matrix. Upper zone of tidal flat. Core Porva Po-89. b) Fabric is characterised by clot clusters that includes foraminifers, bioclasts and fenestral pores occluded by calcite cement. In the transitional zone between the lagoon and tidal flat, the bioclast were redeposited by tidal currents and trapped by biofilm. Core Magyarpolány Mp-37 

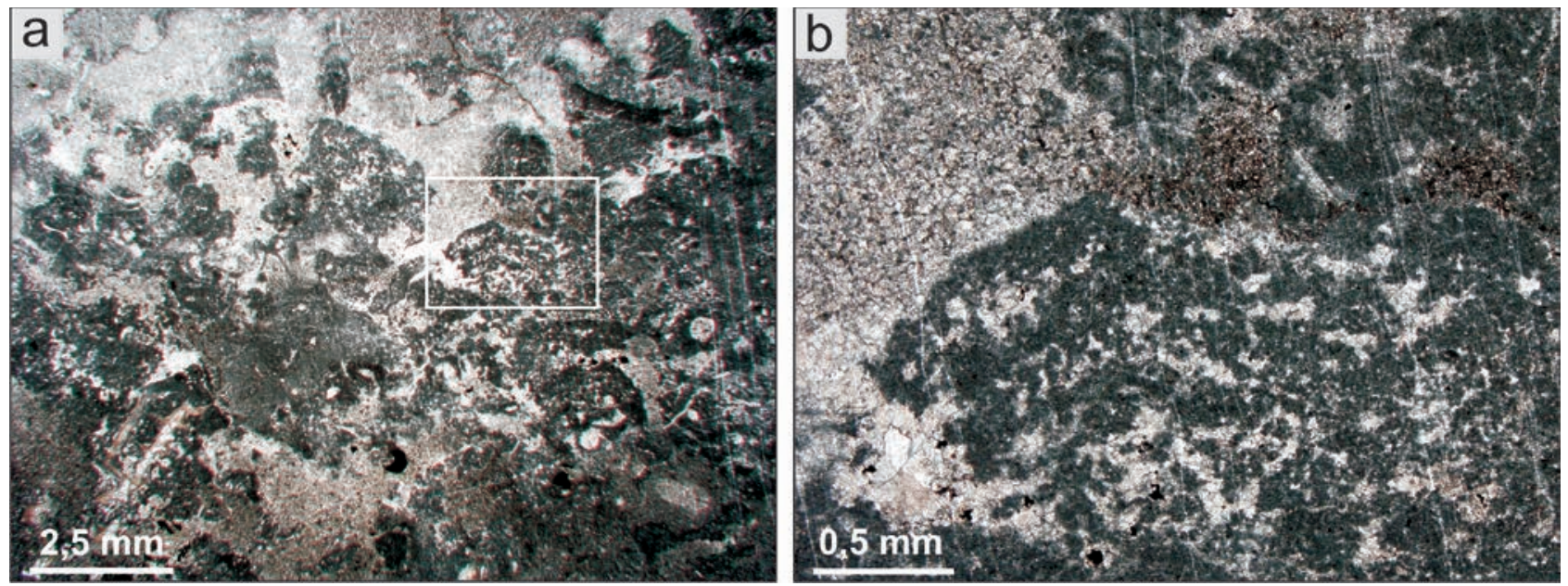

10. ábra. Mikroba boundstone a bükki karbon lencsékből, Mályinkai F. Berenási T., Nagyvisnyó (mikroszkópos fotók)

a) Csomós mikrit szövet átalakult, kristályos foltokkal. b) Az a) ábrának egy részlete (négyszög), ahol a mikritcsomók felfelé elágazó halmazokba rendeződtek, illetve Renalcis kalcimikrobára emlékeztető, vese alakú elemeket formálnak (középen fölül)

Figure 10. Microbial boundstone from Carboniferous limestone lenses, Bükk Mountains, Mályinka Fm, Berenás Mb, Nagyvisnyó (photomicrographs)

a) Clotted micrite fabric with crystalline mottles. b) A detail of the fabric from a) (rectangle), where clots are formed upward branching clusters, and clusters of hollow reniform bodies resemble Renalcis clacimicrobe (top middle)

szövetben jelennek meg, míg a Nagyvisnyó-Putnok vasútvonal mentén feltárt lencsékben a mikrobás csomós mikrit szövethez Fenestella-félékhez tartozó bryozoák és filloid algák társulnak (10. ábra).

Sajátos sztromataktisz szerkezetek ismertek triász (HoRVÁTH \& HIPS 2015) és jura (BARTUS 2014) hemipelágikus és pelágikus környezetben lerakódott karbonátos kőzettestekből. A belső üledékkel és cementtel kitöltött üregek, vagy a több üregból összekapcsolódott üregrendszerek, alul szélesebb és felfelé keskenyedő, elnyúló alakot formálnak, ami arra utal, hogy az üledékben felhalmozódott gázoknak volt szerepe ezen szerkezetek kialakulásában (11. ábra). Az Aggteleki-karszton előforduló triász Nádaskai Mészkő Formációban ez esetenként jellegzetes csomós mikrit szövettel is társul. A hintett automikrit jelenlétére utal a nagy méretú üregek megőrződése.

A Gerecsében a süttői édesvízi mészkőben a csomós mikrit szövet alapján definiálták a mikrobialit litofáciest, amit biofilmből való kalcitkiválásként értelmeztek (TöRÖK et al. 2017). Az egerszalóki hőforrás környezetében kivált édesvízi mészkő boundstone mikrofáciesében a szálas kalcimikroba és a csomós mikrit szöveti komponensek a jel-
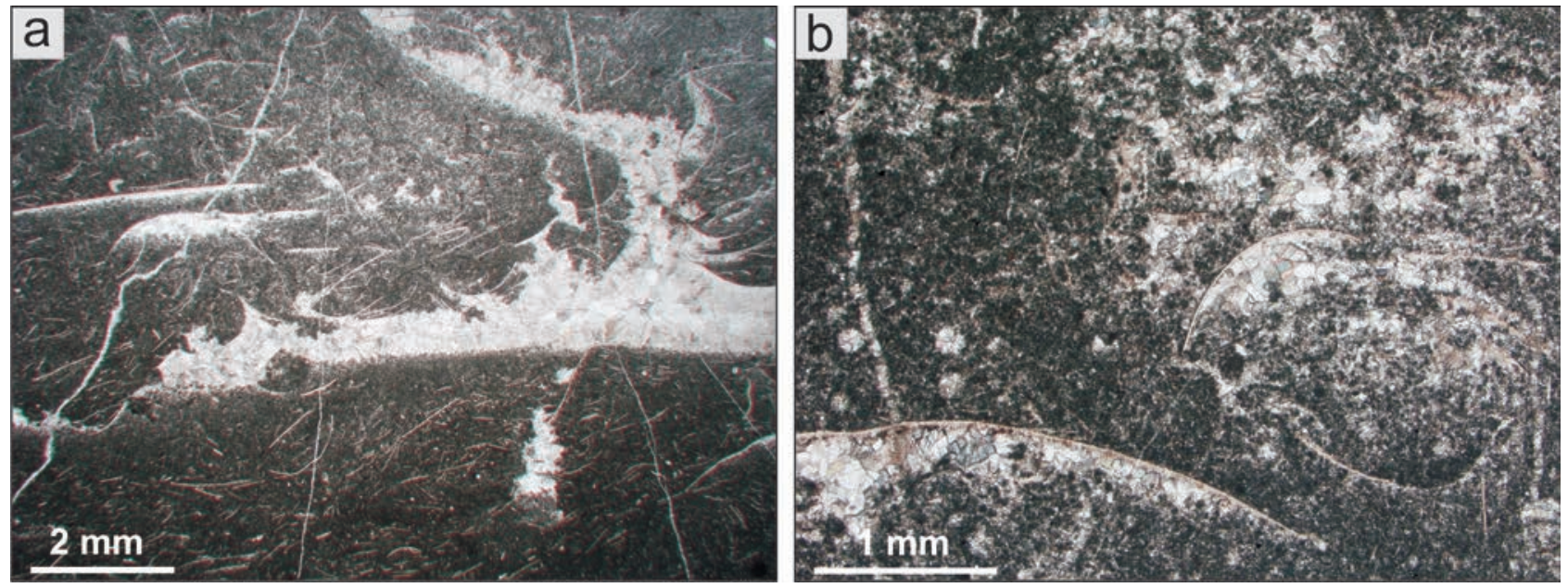

11. ábra. Jellegzetes, cementtel kitöltött pórusok bioklasztos mészkőben (Nádaskai Mészkő F., Szőlősardó Szől-1 fúrás; mikroszkópos fotók)

a) Sztromataktisz szerkezet (HoRvátH \& Hips 2015). Az üreg alsó része lapos, míg a felső része hegyesen felnyúlik és alágazik. A pórust geopetális szerkezetben mikrit belső üledék és kalcitcement tölti ki. b) Bioklasztos boundstone, ahol az automikrit sủrủn és csomókban is megfigyelhető vékony héjú kagylókkal és átalakult radioláriákkal együtt. Kalcitpát cement kitöltésủ védett pórusok és sajátos fenesztrális jellegủ pórusrendszer jellemzi

Figure 11. Characteristic pores in bioclastic limestone (Nádaska Fm, Core Szölösardó Szöl-1; photomicrographs)

a) Stromatactis structure (HORVÁTH \& HIPS 2015). Horizontally elongated void that has an upward-directed and branching protrusion. The pore is occluded by finely crystalline internal sediment and calcite spar cement. b) Bioclastic boundstone, in which dense automicite and clotted micrite occur together with thin-shelled bivalves and radiolarians. Shelter pores and fenestral-like poresystem are occluded by calcite spar cement 
lemzőek. A kapcsolódó biofilmekből pedig extremofil archaeákat azonosítottak (KELE et al. 2008).

\section{Középső-triász szivacs-mikrobazátonyok a} perm végi kihalást követóen

A középső-triász kezdetén kialakult elzárt intraplatform medencében lerakódott karbonátüledékekből jött létre a Gutensteini Mészkő rétegsora. A formáció alsó szakaszán lemezes és vékonyréteges mudstone települ, esetenként lemezes bioklasztos packstone, a felsố szakasza változatos szövetû mészkô és dolomitrétegekből épül fel (HIPs 2003, 2007). A medencében jelentős ökológiai és üledékföldtani változások a szivacsok és a mikroba biofilmek megjelenéséhez köthetôk. A sötétszürke, finomkristályos karbonátrétegsorban a szivacs-mikroba boundstone és az ehhez kapcsolódó fáciestípusok ciklusos, felfelé sekélyesedő tendenciát tükröznek, ahol jellegzetes az ooidos-onkoidos grainstone, a keresztrétegzett és keresztlemezes bioklasztos-peloidos packstone-grainstone, a vékonyréteges bioklasztos wackestone, a gipsz utáni pszeudomorfózákat tartalmazó, lemezes és breccsás dolomit, valamint a pizoidos és finomkristályos dolokrét. A szivacs-mikrobazátonytestek vastagsága 0,5 és 5 m között változik. A párhuzamos rétegfelszínek alapján a finomkristályos karbonát lapos, lencseszerú testeket alkotott, amelyek nem rendelkeztek jelentősebb topográfiai kiemelkedéssel. Mikrofáciesének fontos eleme a szabálytalan, kúpos formákat alkotó bekérgező szivacs, amihez csomós mikrit szövetú komponensek társulnak (12. ábra). Ezek leginkább a szivacson kérgeket, a bioklasztokon kisebb kupacokat vagy klasztereket, és Tubiphytes-szel pedig gumószerü összenövéseket képeznek. A formáció legfelső szakaszán a csomós mikrit szövetú mikroba boundstone képez vastagpados kifejlődést (12. ábra d). Szöveti jellegei
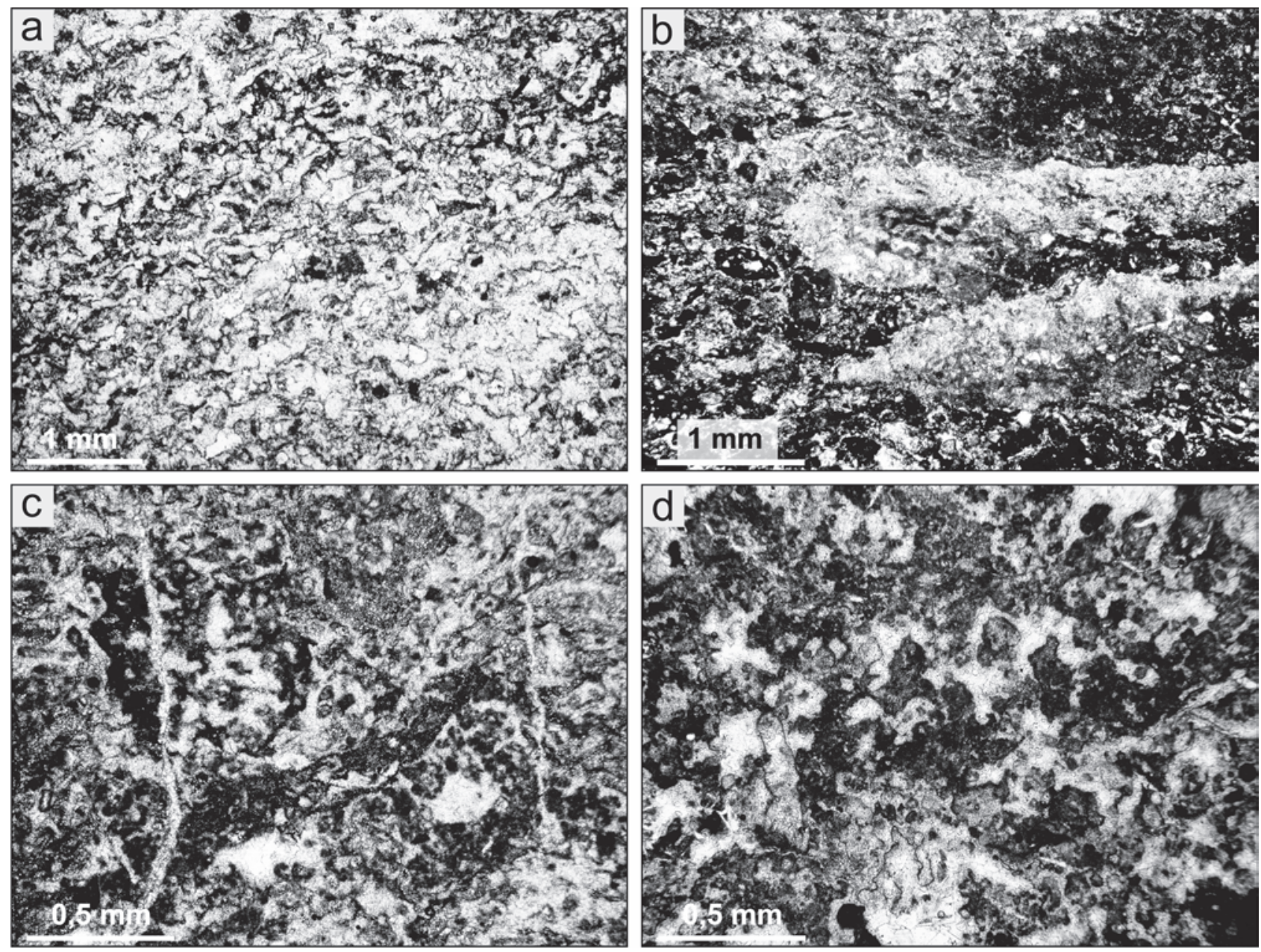

12. ábra. Szivacs-mikrobazátony boundstone mikrofácies típusai, Gutensteini F. (mikroszkópos fotók)

a) Bekérgező szivacsokra jellemző, kalcitpát kristályokból álló kúpos formák (világos), vékony mikrit vagy nagyobb foltokban csomósmikrit-kéreggel (sötét). b) Peloid és bioklasztokat tartalmazó, heterogén felépitésủ csomós mikrit szövetbe lencseszerủen beágyazott mikrit-mikropát alkotta kérgek. c) Bekérgező szivacs kúpos formáival összenőtt, vertikálisan elágazó formákat alkotó csomós mikrit klaszterek. d) Csomósmikrit-halmazok cement kitöltésủ fenesztrális pórusokkal. a), b) és c) Baradla-barlang; d) Kőhorog-oldal, Jósvafőtől északra

Figure 12. Types of sponge-microbe boundstone, Gutenstein Fm (photomicrographs)

a) Characteristic cuneiform shape of encrusting sponge consisting of calcite spars (light) preserved by micrite and clotted micrite crusts (dark). b) Heterogenous clotted micrite fabric includes peloidal and bioclastic grains and lense-shaped micrite-microspar crusts. c) Framework of cuneiform encrusting sponge with clusters of micrite clots. d) Clusters of clotted micite with cement-filled fenestral pores. a), b) and c) Baradla Cave; d) Köhorog roadcut, north of Jósvafó 
fokozatos átmenetet mutatnak a fedő Steinalmi Formáció onkoidos sztromatolit fáciese felé. Az Északi-Mészkőalpok, a Nyugati-Kárpátok és a Dinaridák rétegsorában is megjelennek ezek a sötétszürke, finomkristályos mikrobialitok, ahol jellegzetes szöveti elem a klasztereket alkotó csomós mikrit (HIPS 2007). A perm végi kihalást követően az élővilág evolúciójának jelentős lépcsőfoka volt ez a középső-triász szakasz, mely megelőzte a jelentősebb metazoa zátonyok kialakulását.

\section{Mikrobazátonyok a Dachsteini platform külsó övezetében}

A Dunántúli-középhegységi-egység északkeleti részének üledéklerakódási területe a késő-triász idején a Dachsteini platformrendszer intraplatform medencékkel tagolt külső övezetét képezte. Ezek a képződmények a Budaihegyekben, valamint a Duna-balparti-rögök területén vannak feltárva. Itt a Dachsteini Mészkő kifejlődése a belsô platformra jellemző Lofer-ciklusos rétegsorokétól jelentősen eltér. A tagolatlan, 5-6 m vastagságot is eléró padokat uralkodóan onkoidszemcsék alkotják. A Budai-hegyekben, a Remete-hegy térségében ismert, ősmaradványokban gazdag előfordulásról ezt a képződményt Remetehegyi Tagozatként különítették el (HAAs \& BUDAI 2014).

A típusterület rétegsorainak mikrofácies vizsgálata arra az eredményre vezetett, hogy a vastag padokat litofáciestípusokba sorolható mészkőfajták építik fel. Ezek uralkodó hányadának képződésében a mikrobák meghatározó szerepet játszhattak (HoRváTH \& HAAs 2014). A padok bázisán olykor kis vastagságban sztromatolit jelenik meg. A többi boundstone mikrofácies a kalcimikrobás, szemcseaggregá- tumos és onkoidos, valamint a bioklasztos litofáciesekbe sorolhatóak. A kalcimikrobás litofáciesben, a régi terminus szerinti Porostromata-csoportba (FLÜGEL 2004) tartozó Cayeuxia és Ortonella ismerhetô fel (13. ábra). Ezek a fonalas kalcimikroba formák a jelenkori tavi környezetekből ismert Rivularia kalcimikroba típussal azonosíthatóak (DRAGASTAN et al. 1996). Ezekkel együtt gyakran szabálytalan alakú vagy lencseszerú Thaumatoporellák is megjelennek. Az onkoidos litofácies esetében az onkolit kôzet uralkodóan több milliméteres onkoidszemcsékből áll, melyekben a bekérgezett szemcsék magjaként kalcimikroba-töredékek, továbbá különböző szervezetek mészvázának töredékei jelennek meg. Szinte valamennyi litofácies-típusban jelen vannak a néhány milliméteres szemcseaggregátumok, amelyek csomós mikrittel/automikrittel cementált apró karbonátszemcsékből állnak, de van olyan fáciestípus is, amelyben ezek az összetett szemcsék kőzetalkotó mennyiségben vannak jelen.

A fent említett litofácies-típusok esetében a szemcsék között általában csomós mikrit figyelhetô meg, ami helyben, a biofilmmátrixban történt kiválásra utal. A kalcimikrobák és a drúzás kalcitpát cementtel kitöltött makroszkópos fenesztrális pórusok jelenléte a több méter vastagságot elérô rétegzetlen/tagolatlan boundstone padokban arra utal, hogy ez a képződmény mikrobazátonyként értelmezhetô. Hasonló mikrobazátony ismert a Dachsteini Mészkő szerbiai előfordulásából (HIPS et al. 2011). A boundstone típusú kőzetek mellett erôsebben mozgatott sekélytengeri környezetben lerakódott grainstone és gyenge vízmozgású védett környezetben képződött pelletes wackestone litofáciesek is jelen vannak a rétegsorban. Ezek a
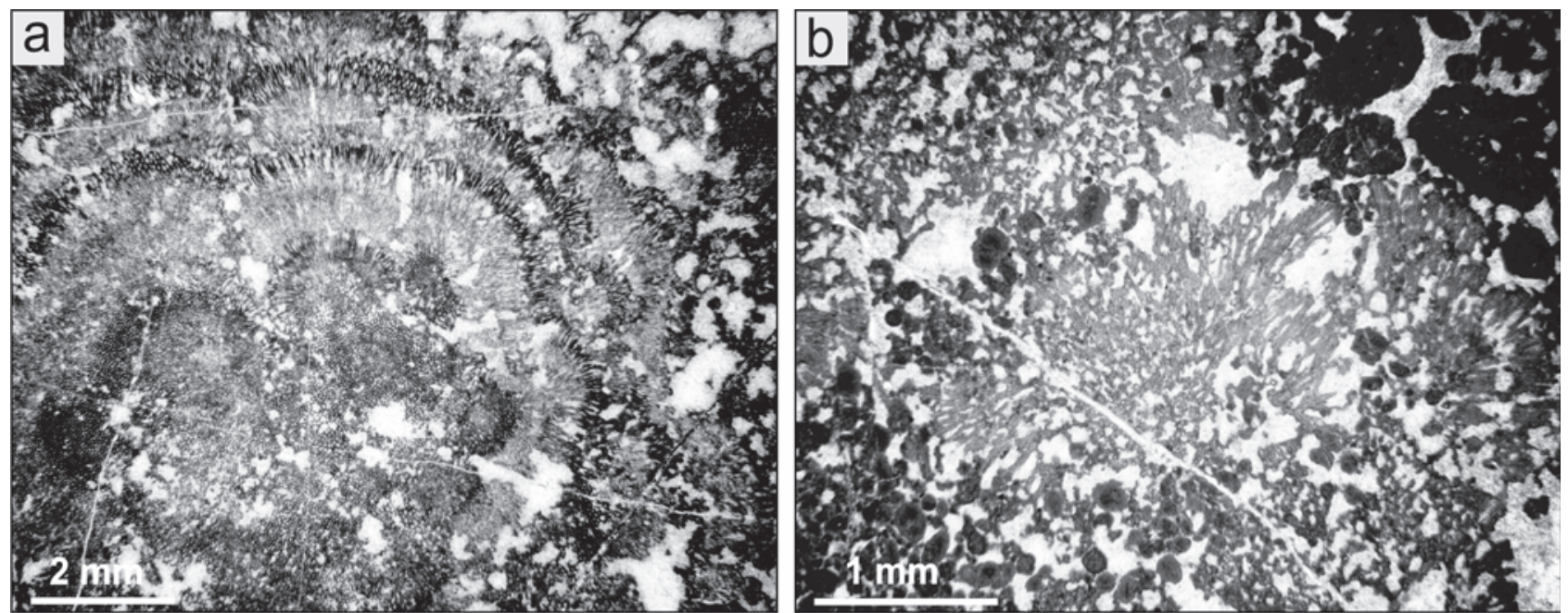

13. ábra. Kalcimikrobák a mikrobazátony boundstone mikrofácieseiben, Dachsteini F. Remetehegyi T., Nézsa (mikroszkópos fotók)

a) Félgömböt formáló, fonalas szerkezetủ kalcimikroba keresztmetszetben, radiaxiális rostos kalcitcement-kitöltésű fenesztrális pórusokkal. Szintekben sötétebb és világosabb sávok jelzik a kicsapódott karbonát eltérő kristályméretét, ami a kristálycsíra-képződésnek és a szerves mátrix szerkezeti megőrződésének függvénye. b) Fonalas kalcimikroba klaszterek (középen) kapcsolódása a csomós mikrit szövettel (balra fent), onkoidokkal (jobbra fent) és kalcitcement kitöltésủ fenesztrális pórusokkal

Figure 13. Calcimicrobes in microbial reef boundstone, Dachstein Fm, Remetehegy Mb, Nézsa (photomicrographs)

a) Cross section through filamentous calcimicrobe forming half-sphere and fenestral pores occluded by radiaxial fibrous calcite cement. Darker and lighter bands refers to various crystal size that were formed in the function of crystal nucleation and preservation of structure of organic matrix. b) Clusters of filamentous calcimicrobe (middle), clotted micrite (upper left), oncoids (upper right) and fenestral pores occluded by calcite spars 
típusok a mikrobazátonyok körzetében képződtek, térben és időben változó környezeti feltételek mellett (HoRvÁTH \& HAAS 2014).

\section{Zárógondolatok}

A karbonátos kőzetek jelentős szerepet játszanak a litoszféra legfelső részének felépítésében. Hatalmas hegységvonulatok uralkodó hányadát alkotják, kiterjedt fennsíkokat építenek fel, medencék aljzatát képezik. Ennek ellenére a 20. század derekáig igen csekély megalapozott ismerettel rendelkeztünk e kőzetfajták képződésének körülményeirôl. Az első áttörést ezen a téren a múlt század '50-es éveiben megkezdődött aktuálgeológiai vizsgálatok jelentették, amelyek eredményei szinte azonnal beépültek a karbonátos szénhidrogén-tárolók éppen ekkor felfutó kutatásainak gyakorlatába. A következő áttörést a mélytengerek kutatását célzó fúrási programok adták, amelyek a mélytengeri karbonátos kőzetek képződésének megértéséhez nyitották meg a kaput.

A harmadik jelentős fordulatra a múlt század utolsó évtizedeiben került sor, amikor felismerték azt, hogy a mikrobáknak sokkal nagyobb a szerepük a mészkövek képződésében és a mészüledékek kőzetté válásában, mint azt korábban feltételezték. Ez sok tekintetben megváltoztatta a kutatók szemléletét, a kutatások módszereit és esetenként a korábbi képződési modellek számottevő módosulásához, nem egyszer gyökeres megváltozásához vezettek. A felismerés hátterét a mikrobiológus és szedimentológus csoportok által végzett kiterjedt aktuálgeológiai kutatási programok mellett a laboratóriumi kísérleti lehetôségek, továbbá az anyagvizsgálati módszerek rendkívül gyors fejlődése adta.

A mikrobák szerepe a mészkő képződésében nem korlátozódik csupán a mikrobialit kôzetfajták létrehozására. Ennél sokkal több mikrobák közremúködésével végbemenő folyamat ismert, amely más mészkőfajták, dolomitok vagy egyéb kőzetek diagenezisében lényeges szerepet játszik. A rövid áttekintésből is kitûnik, hogy a hazai mészkőfajták között is jelentős számban vannak a mikrobialitok csoportjába sorolhatók. Ezek közül néhány esetében már megkezdődtek az új szemlélettel, módszerekkel és korszerú anyagvizsgálati eszközökkel folyó kutatások. Kétségtelen azonban, hogy igen sok tennivaló van ezen a téren. Ismereteink bővítése, korábbi megcsontosodott nézeteink felülvizsgálata, a képződési modellek újragondolása és mindenek előtt új célirányos kutatások szükségesek ahhoz, hogy a magyarországi karbonátos rétegsorok vizsgálatában követni tudjuk a karbonátszedimentológia ezirányú nagy ütemú nemzetközi fejlődését.

\section{Köszönetnyilvánítás}

Hálás köszönetünket fejezzük ki a cikk lektorainak, PIROs Olgának és MoHr Emőkének javaslataikért.

\section{Irodalom - References}

ADDADI, L. \& WEINER, S. 1992: Control and design principles in biological mineralization. — Angewandte Chemie International Edition in English 31/2, 153-169. https://doi.org/10.1002/anie.199201531

AgirRezabala, L. M. 2009: Mid Cretaceous hydrothermal vents and authigenic carbonates in a transform margin, Basque Cantabrian Basin (western Pyrenees): a multidisciplinary study. — Sedimentology 56/4, 969-996. https://doi.org/10.1111/j.1365-3091.2008. 01013.x

AitKEN, J. D. 1967: Classification and environmental significance of cryptalgal limestones and dolomites, with illustrations from the Cambrian and Ordovician of southwestern Alberta. — Journal of Sedimentary Research 37/4, 1163-1178. https://doi.org/10.1306/ 74D7185C-2B21-11D7-8648000102C1865D

Allen, M. A., GoH, F., BuRns, B. P. \& NeILAN, B. A. 2009: Bacterial, archaeal and eukaryotic diversity of smooth and pustular microbial mat communities in the hypersaline lagoon of Shark Bay. — Geobiology 7/1, 82-96. https://doi.org/10.1111/j.1472-4669.2008. 00187.x

ANDRES, M. S. \& REID, R. P. 2006: Growth morphologies of modern marine stromatolites: a case study from Highborne Cay, Bahamas. - Sedimentary Geology 185/3-4, 319-328. https://doi.org/10.1016/j.sedgeo.2005.12.020

Arp, G., Reimer, A. \& ReITner, J. 1999a: Calcification in cyanobacterial biofilms of alkaline salt lakes. — European Journal of Phycology 34/4, 393-403. https://doi.org/10.1080/09670269910001736452

ARp, G., Thiel, V., Reimer, A., Michaelis, W. \& Reitner, J. 1999b: Biofilm exopolymers control microbialite formation at thermal springs discharging into the alkaline Pyramid Lake, Nevada, USA. — Sedimentary Geology 126/1-4, 159-176. https://doi.org/ 10.1016/S0037-0738(99)00038-X

Arp, G., Reimer, A. \& ReItNer, J. 2001: Photosynthesis-induced biofilm calcification and calcium concentrations in Phanerozoic oceans. — Science 292/5522, 1701-1704. https://doi.org/10.1126/science.105720

Awramik, S. M., Schopf, J. W. \& Walter, M. R. 1983: Filamentous fossil bacteria from the Archean of Western Australia. Developments in Precambrian Geology 7, 249-266 https://doi.org/10.1016/S0166-2635(08)70251-2 .

Balog, A., READ, J. F. \& HAAS, J. 1999: Climate-controlled early dolomite, Late Triassic cyclic platform carbonates, Hungary. Journal of Sedimentary Research 69/1, 267-282. https://doi.org/10.1306/D42689CD-2B26-11D7-8648000102C1865D

BARTUS G. 2014: A gerecsei tithon hierlatz típusú mészkő képződési környezete szedimentológiai és paleoökológiai vizsgálatok alapján. Szakdolgozat, Általános és Alkalmazott Földtani Tanszék, Eötvös Loránd Tudományegyetem.

Bathurst, R. G. C. 1971: Carbonate sediments and their diagenesis — Developments in Sedimentology 12, 620. 
Bathurst, R. G. C. 1980: Stromatactis—Origin related to submarine-cemented crusts in Paleozoic mud mounds. — Geology 8/3, 131134. https://doi.org/10.1130/0091-7613(1980)8<131:SRTSCI >2.0.CO;2

Baumgartner, L. K., Reid, R. P., Dupraz, C., Decho, A. W., Buckley, D. H., Spear, J. R., Przekop, K. M. \& Visscher, P. T. 2006 : Sulfate reducing bacteria in microbial mats: changing paradigms, new discoveries. - Sedimentary Geology 185/3-4, 131-145. https://doi.org/10.1016/j.sedgeo.2005.12.008

Beauchamp, B. \& Savard, M. 1992: Cretaceous chemosynthetic carbonate mounds in the Canadian Arctic. — Palaios 434-450. https://doi.org/10.2307/3514828

Beauchamp, B. \& Von BitTer, P. 1992: Chemo What? — Palaios 7/4, 337.

Beltrán, Y., Cerqueda-García, D., TAŞ, N., Thomé, P. E., Iglesias-Prieto, R. \& Falcón, L. I. 2016: Microbial composition of biofilms associated with lithifying rubble of Acropora palmata branches. — FEMS Microbiology Ecology 92/1, https://doi.org/10.1093/ femsec/fiv 162

BEN YAAKOV, S. 1973: pH buffering of pore water of recent anoxic marine sediments. — Limnology and Oceanography 18/1, 86-94. https://doi.org/10.4319/lo.1973.18.1.0086

Bércziné Makk A., KonRÁd Gy., RÁlischné Felgenhauer E. \& TöröK Á. 2004: Tiszai egység. — In: HaAs J. (szerk.): Magyarország geológiája. Triász. 303-360 ELTE Eötvös Kiadó.

Birgel, D., Meister, P., Lundberg, R., Horath, T. D., Bontognali, T. R. R., Bahniuk, A. M., De Rezende, C. E., VÁsconcelos, C. \& McKenzIE, J. A. 2015: Methanogenesis produces strong 13C enrichment in stromatolites of Lagoa Salgada, Brazil: a modern analogue for Palaeo /Neoproterozoic stromatolites? — Geobiology 13/3, 245-266. https://doi.org/10.1111/gbi.12130

BLACK, M. 1933: The algal sediments of Andros Island, Bahams Bank. — Philosophical Transactions of the Royal Society of London, Series B 222, 165-192.

Bosence, D. W. J. \& Bridges, P. H. 1995: A review of the origin and evolution of carbonate mud mounds. - In: MonTy, C. L. V., Bosence, D. W. J., Bridges, P. H. \& Pratt, B. R. (eds): Carbonate mud mounds: Their origin and evolution. Number 23, 1-9. Special Publication of the International Association of Sedimentologists and Blackwell Science Ltd.

Bourque, P. A. 2001: Mud-mounds: do they still constitute an enigma? - Géologie Méditerranéenne 28/1, 27-32. https://doi.org/ 10.3406/geolm.2001.1683

Bourque, P.-A. \& Boulvain, F. 1993: A model for the origin and petrogenesis of the red stromatactis limestone of Paleozoic carbonate mounds. - Journal of Sedimentary Research 63/4, 607-619. https://doi.org/10.1306/D4267B8B-2B26-11D7-8648000102C1865D

Braga, J. C., Puga-Bernabéu, Á., Heindel, K., Patterson, M. A., Birgel, D., Peckmann, J., Sánchez-Almazo, I. M., Webster, J. M., YoKOYAMA, Y. \& RIDING, R. 2019: Microbialites in Last Glacial Maximum and deglacial reefs of the Great Barrier Reef (IODP Expedition 325, NE Australia). - Palaeogeography, Palaeoclimatology, Palaeoecology 514, 1-17. https://doi.org/10.1016/j.palaeo.2018.10.007

BraithwAtte, C. J. R. \& ZeDEF, V. 1996: Hydromagnesite stromatolites and sediments in an alkaline lake, Salda Golu, Turkey. — Journal of Sedimentary Research 66/5, 991-1002. https://doi.org/10.1306/D426845F-2B26-11D7-8648000102C1865D

Brock, T. D., Madigan, M. T., Martinko, J. M. \& Parker, J. 1994: Biology of Microorganisms. — Prentice Hall Upper Saddle River, New Jersey 648, 650 .

BuCZYNSKI, C. \& CHAFETZ, H. S. 1991: Habit of bacterially induced precipitates of calcium carbonate and the influence of medium viscosity on mineralogy. - Journal of Sedimentary Research 61/2, 226-233. https://doi.org/10.1306/D42676DB-2B26-11D7$8648000102 \mathrm{C} 1865 \mathrm{D}$

Burne, R. V. \& Moore, L. S. 1987: Microbialites; organosedimentary deposits of benthic microbial communities. — Palaios 2/3, 241254. https://doi.org/10.2307/3514674

Cabioch, G., Camoin, G., Webb, G. E., Le Cornec, F., Molina, M. G., Pierre, C. \& Joachimski, M. M. 2006: Contribution of microbialites to the development of coral reefs during the last deglacial period: case study from Vanuatu (South-West Pacific). Sedimentary Geology 185/3-4, 297-318. https://doi.org/10.1016/j.sedgeo.2005.12.019

Camoin, G. F. \& MontagGioni, L. F. 1994: High energy coralgal stromatolite frameworks from Holocene reefs (Tahiti, French Polynesia). — Sedimentology 41/4, 655-676. https://doi.org/10.1111/j.1365-3091.1994.tb01416.x

CAMoin, G. \& GaUtRet, P. 2006: Microbialites and microbial communities: Biological diversity, biogeochemical functioning, diagenetic processes, tracers of environmental changes. — Sedimentary Geology 185, 127-130. https://doi.org/10.1016/j.sedgeo.2005.12.007

Camoin, G. F., Gautret, P., Montaggioni, L. F. \& Cabioch, G. 1999: Nature and environmental significance of microbialites in Quaternary reefs: the Tahiti paradox. - Sedimentary Geology 126/1-4, 271-304. https://doi.org/10.1016/S0037-0738(99)00045-7

CANField, D. E., Raiswell, R., Allison, P. A. \& BRigGs, D. E. G. 1991: Carbonate precipitation and dissolution: its relevance to fossil preservation. - Taphonomy: Releasing the data locked in the fossil record 9, 412-453.

Castanier, S., Le Métayer-Levrel, G. \& Perthuisot, J.-P. 1999: Ca-carbonates precipitation and limestone genesis-the microbiogeologist point of view. - Sedimentary Geology 126/1-4, 9-23. https://doi.org/10.1016/S0037-0738(99)00028-7

CAYEUX, L. 1935: Les roches sédimentaires de France: roches carbonatées. — Masson-Paris.

CHAFETZ, H. S. 1986: Marine peloids; a product of bacterially induced precipitation of calcite. — Journal of Sedimentary Research 56/6, 812-817. https://doi.org/10.1306/212F8A58-2B24-11D7-8648000102C1865D

ChafeTZ, H. S. \& BuCZYNSKI, C. 1992: Bacterially induced lithification of microbial mats. — Palaios 277-293. https://doi.org/10.2307/ 3514973

ChafeTZ, H. S. \& FolK, R. L. 1984: Travertines; depositional morphology and the bacterially constructed constituents. - Journal of Sedimentary Research 54/1, 289-316. https://doi.org/10.1306/212F8404-2B24-11D7-8648000102C1865D

ChafeTz, H. S. \& GUIDRY, S. A. 1999: Bacterial shrubs, crystal shrubs, and ray-crystal shrubs: bacterial vs. abiotic precipitation. Sedimentary Geology 126/1-4, 57-74. https://doi.org/10.1016/S0037-0738(99)00032-9

Colín-García, M., Heredia, A., Cordero, G., Camprubí, A., Negrón-Mendoza, A., Ortega-Gutiérrez, F., Beraldi, H. \& 
Ramos-Bernal, S. 2016: Hydrothermal vents and prebiotic chemistry: a review. - Boletín de la Sociedad Geológica Mexicana 68/3, 599-620.

Costerton, J. W. \& LAPPIn-SCOTt, H. M. 1995: Introduction to microbial biofilms. — In: LAPPIN-SCOtT, H. M. \& Costerton, J. W. (eds): Microbial biofilms 1-11. Cambridge: Cambridge University Press.

Csásż́r, G. 2002: Urgon formations in Hungary. — Geologica Hungarica Series Geologia 25, 1-209.

Decho, A. W. 1990: Microbial exopolimer as a stucturing agent for heterogeneity within microbial biofilms. — In: RIDING, R. \& AwrAmiK, S. M. (eds): Microbial Sediments 9-15. Heidelberg: Springer-Verlag.

Decho, A. W. 2010: Overview of biopolymer-induced mineralization: what goes on in biofilms? - Ecological Engineering 36/2, 137144. https://doi.org/10.1016/j.ecoleng.2009.01.003

DeFarge, C., Trichet, J., Jaunet, A.-M., Robert, M., Tribble, J. \& Sansone, F. J. 1996: Texture of microbial sediments revealed by cryo-scanning electron microscopy. — Journal of Sedimentary Research 66/5, 935-947. https://doi.org/10.1306/D4268446-2B2611D7-8648000102C1865D

Dill, R. F., Shinn, E. A., Jones, A. T., Kelly, K. \& Steinen, R. P. 1986: Giant subtidal stromatolites forming in normal salinity waters. - Nature 324/6092, 55-58.

DonG, H. \& Yu, B. 2007: Geomicrobiological processes in extreme environments: A review. — Episodes 30/3, 202. https://doi.org/ 10.18814/epiiugs/2007/v30i3/003

Dragastan, O., Golubic, S. \& Richter, D. K. 1996: Rivularia haematites: a case of the recent versus fossil morphology. Taxonomical considerations. - Revista Espanola de Micropaleontologia 28, 43-74.

DREw, G. H. 1911: The action of some denitrifying bacteria in tropical and temperate seas, and the bacterial precipitation of calcium carbonate in the sea. - Journal of the Marine Biological Association of the United Kingdom 9/2, 142-155. https://doi.org/10.1017/ S0025315400073318

DUPRAZ, C. \& VisSCHER, P. T. 2005: Microbial lithification in marine stromatolites and hypersaline mats. — Trends in Microbiology 13/9, 429-438. https://doi.org/10.1016/j.tim.2005.07.008

Dupraz, C., Visscher, P. T., Baumgartner, L. K. \& Reid, R. P. 2004: Microbe-mineral interactions: early carbonate precipitation in a hypersaline lake (Eleuthera Island, Bahamas). — Sedimentology 51/4, 745-765. https://doi.org/10.1111/j.1365-3091.2004.00649.x

Dupraz, C., Pattisina, R. \& Verrecchia, E. P. 2006: Translation of energy into morphology: simulation of stromatolite morphospace using a stochastic model. — Sedimentary Geology 185/3-4, 185-203. https://doi.org/10.1016/j.sedgeo.2005.12.012

Dupraz, C., Reid, R. P., Braissant, O., Decho, A. W., Norman, R. S. \& Visscher, P. T. 2009: Processes of carbonate precipitation in modern microbial mats. — Earth-Science Reviews 96/3, 141-162. https://doi.org/10.1016/j.earscirev.2008.10.005

EHRLICH, H. L. 1998: Geomicrobiology: its significance for geology. — Earth-Science Reviews 45/1-2, 45-60. https://doi.org/10.1016/ S0012-8252(98)00034-8

Enyedi, N. T., MakK, J., Kótai, L., Berényi, B., Klébert, S., Sebestyén, Z., Molnár, Z., Borsodi, A. K., LeÉl-Őssy, S. \& Demény, A. 2020: Cave bacteria-induced amorphous calcium carbonate formation. — Scientific Reports 10/8696, 1-12. https://doi.org/10.1038/ s41598-020-65667-w

Fischer, A. G. 1964: The Lofer cyclothem of the Alpine Triassic In. — In: Symposium on cyclic sedimentation. Kansas State Geological Survey Bulletin 169/1, 107-149.

Flajs, G., Vigener, M., Keupp, H., Meischner, D., Neuweiler, F., Paul, J., Reitner, J., Warnke, K., Weller, H. \& Dingle, P. 1995 : Mud mounds: a polygenetic spectrum of fine-grained carbonate buildups. — Facies 32/1, 1-69. https://doi.org/10.1007/BF02536864

Flemming, H.-C. \& WingendeR, J. 2010: The biofilm matrix. — Nature Reviews Microbiology 8/9, 623-633. https://doi.org/10.1038/ nrmicro2415

FLÜGEL, E. 2004: Microfacies analysis of carbonate rocks Berlin: Analysis, Interpretation and Application. — Springer.

FlÜGEL, E., Hillmer, G. \& SCHOLZ, J. 1993: Microbial carbonates and reefs. An introduction. — Facies 29, 1-2. https://doi.org/10.1007/ BF02536914

FOLK, R. L. 1959: Practical petrographic classification of limestones. - AAPG Bulletin 43/1, 1-38.

FoLK, R. L. 1993: SEM imaging of bacteria and nannobacteria in carbonate sediments and rocks. — Journal of Sedimentary Research 63/5, 990-999. https://doi.org/10.1306/D4267C67-2B26-11D7-8648000102C1865D

FOLK, R. L. \& LYNCH, F. L. 2001: Organic matter, putative nannobacteria and the formation of ooids and hardgrounds. - Sedimentology 48/2, 215-229. https://doi.org/10.1046/j.1365-3091.2001.00354.x

Freytet, P. \& VerReCChiA, E. P. 1998: Freshwater organisms that build stromatolites: a synopsis of biocrystallization by prokaryotic and eukaryotic algae. - Sedimentology 45/3, 535-563. https://doi.org/10.1046/j.1365-3091.1998.00155.x

FüLÖP J. 1975: Tatai mezozoós alaphegység rögök. — Geologica Hungarica Series Geologia 16, 225.

FÜLÖP J. (szerk.) 1990: Magyarország geológiája. Paleozoikum I. — Budapest: Magyar Állami Földtani Intézet.

FÜLÖP J.(szerk.) 1994: Magyarország geológiája, Paleozoikum II. — Budapest: Akadémiai Kiadó.

GebeLIN, C. 1969: Distribution, morphology and accretion rate of recent subtidal algal stromatolites, Bermuda. — Journal of Sedimentary Petrology 39, 49-69. https://doi.org/10.1306/74D71BE0-2B21-11D7-8648000102C1865D

GinsBURG, R. N. \& LOWENSTAM, H. A. 1958: The influence of marine bottom communities on the depositional environment of sediments. — The Journal of Geology 66/3, 310-318. https://doi.org/10.1086/626507

GócZÁn F., HAAS J., LóRINCZ H. \& ORAVECZnÉ SchefFer A. 1993: Keszthelyi-hegységi karni alapszelvény faciológiai és rétegtani értékelése (Hévíz-6. sz. fúrás). — A Magyar Állami Földtani Intézet Évi Jelentése 1981-rôl, 263-293.

GradzIŃSKI, M., TYSZKA, J., UCHMAN, A. \& JACH, R. 2004: Large microbial-foraminiferal oncoids from condensed Lower-Middle Jurassic deposits: a case study from the Tatra Mountains, Poland. - Palaeogeography, Palaeoclimatology, Palaeoecology 213/1-2, 133-151. https://doi.org/10.1016/j.palaeo.2004.07.010 
Grotzinger, J. P. 1989: Facies and evolution of Precambrian carbonate depositional systems: emergence of the modern platform archetype. - In: Crevello, P. D., Wilson, J. L., SARG, J. F. \& ReAd, J. F. (eds): Controls on Carbonate Platform and Basin Development 44, 79-106. Special Publications of SEPM.

HAAS, J. 1988: Upper Triassic carbonate platform evolution in the Transdanubian Mid-Mountains. — Acta Geologica Hungarica 31/34, 299-312.

HaAs, J. 1991: A basic model for Lofer cycles. — In: Einsele, G., Ricken, W. \& SeILACHER, A. (eds): Cycles and events in stratigraphy 722-732. Heidelberg: Springer-Verlag Berlin.

HAAS, J. 2002: Origin and evolution of Late Triassic backplatform and intraplatform basins in the Transdanubian Range, Hungary. Geologica Carpathica 53/3, 159-178.

HAAS, J. 2004: Characteristics of peritidal facies and evidences for subaerial exposures in Dachstein-type cyclic platform carbonates in the Transdanubian Range, Hungary. — Facies 50/2, 263-286. https://doi.org/10.1007/s10347-004-0021-x

HaAs, J. \& BudaI, T. 1995: Upper Permian - Triassic facies zones in the Transdanubian Range. — Rivista Italiana di Paleontologia e Stratigrafia 101/3, 249-266. https://doi.org/10.13130/2039-4942/8587

HAAS J. \& BUDAI T. 2014: A Dunántúli-középhegység felsô-triász képződményeinek rétegtani- és fácieskérdései. — Földtani Közlöny $144 / 2,125-142$.

HaAs J., Jocha-Edelényi E., Gidai L., Kaiser M. \& Kretzor M. 1984: Sümeg és köryékének földtani félépítése. — Geologica Hungarica Series Geologica 20, 1-353.

HaAs, J., Kovács, S., Krystyn, L. \& Lein, R. 1995: Significance of Late Permian - Triassic facies zones in terrane reconstructions in the Alpine-North Pannonian domain. — Tectonophysics 242/1-2, 19-40. https://doi.org/10.1016/0040-1951(94)00157-5

HAAS J. ,BUdAi T., HiPs K. \& KRIVÁNnÉ HoRvÁTH Á. 2004: Magyarország geológiája. Triász. — Budapest, ELTE Eötvös Kiadó

HaAs, J., Demény, A., Hips, K., Zajzon, N., Weiszburg, T. G., Sudar, M. \& PÁlfy, J. 2007: Biotic and environmental changes in the Permian-Triassic boundary interval recorded on a western Tethyan ramp in the Bükk Mountains, Hungary. — Global and Planetary Change 55/1-3, 136-154. https://doi.org/10.1016/j.gloplacha.2006.06.010

HAAS, J., BUDAI, T. \& RAUCSIK, B. 2012: Climatic controls on sedimentary environments in the Triassic of the Transdanubian Range (Western Hungary). - Palaeogeography, Palaeoclimatology, Palaeoecology 353, 31-44. https://doi.org/10.1016/j.palaeo.2012. 06.031

HaAs, J., Lukoczki, G., Budai, T. \& DemÉny, A. 2015: Genesis of upper Triassic peritidal dolomites in the Transdanubian Range, Hungary. - Facies 61/3, 8. https://doi.org/10.1007/s10347-015-0435-7

Heindel, K., WisshaK, M. \& WeSTPHAL, H. 2009: Microbioerosion in Tahitian reefs: a record of environmental change during the last deglacial sea level rise (IODP 310). — Lethaia 42/3, 322-340. https://doi.org/10.1111/j.1502-3931.2008.00140.x

Heindel, K., Birgel, D., Peckmann, J., Kuhnert, H. \& Westphal, H. 2010: Formation of deglacial microbialites in coral reefs off Tahiti (IODP 310) involving sulfate-reducing bacteria. — Palaios 25/10, 618-635. https://doi.org/10.2110/palo.2010.p10-032r

Heindel, K., Birgel, D., Brunner, B., Thiel, V., Westphal, H., Gischler, E., Ziegenbalg, S. B., Cabioch, G., Suövall, P. \& Peckmann, J. 2012: Post-glacial microbialite formation in coral reefs of the Pacific, Atlantic, and Indian Oceans. - Chemical Geology 304, 117-130. https://doi.org/10.1016/j.chemgeo.2012.02.009

Hillgärtner, H., Dupraz, C. \& Hug, W. 2001: Microbially induced cementation of carbonate sands: are micritic meniscus cements good indicators of vadose diagenesis? - Sedimentology 48/1, 117-131. https://doi.org/10.1046/j.1365-3091.2001.00356.x

HIPS K. 2003: Gutensteini Formáció a Szilicei takaró Aggteleki fáciesében.(Gutenstein Formation in the Aggtelek facies of the Silica nappe). - Földtani Közlöny 133/4, 445-468.

HIPS, K. 2007: Facies pattern of western Tethyan Middle Triassic black carbonates: The example of Gutenstein Formation in Silica Nappe, Carpathians, Hungary, and its correlation to formations of adjoining areas. — Sedimentary Geology 194/1-2, 99-114. https://doi.org/ 10.1016/j.sedgeo.2006.05.001

HIPS, K. \& HAAS, J. 2006: Calcimicrobial stromatolites at the Permian-Triassic boundary in a western Tethyan section, Bükk Mountains, Hungary. — Sedimentary Geology 185/3-4, 239-253. https://doi.org/10.1016/j.sedgeo.2005.12.016

Hips, K., HaAs, J., Vido, M., Barna, Z., Jovanović, D., Sudar, M. N. \& Siklosy, Z. 2011: Selective blackening of bioclasts via mixing zone aragonite neomorphism in Late Triassic limestone, Zlatibor Mountains, Serbia. — Sedimentology 58/4, 854-877. https://doi.org/10.1111/j.1365-3091.2010.01186.x

Hoffman, P. 1974: Shallow and deepwater stromatolites in Lower Proterozoic platform-to-basin facies change, Great Slave Lake, Canada. - AAPG Bulletin 58/5, 856-867. https://doi.org/10.1306/83D914A7-16C7-11D7-8645000102C1865D

HofMANN, H. J. 2000: Archean stromatolites as microbial archives. — In: RIDING, R. \& AwRAMIK, S. M. (eds): Microbial sediments 315327. Heidelberg: Springer-.

Horvath, B. \& HiPs, K. 2015: Microfacies associations of Middle and Upper Triassic slope and basin carbonates deposited along the Neo-Tethyan margin, NE Hungary. — Austrian Journal of Earth Sciences 108/1, 34-49. https://doi.org/10.17738/ajes.2015. 0003

Horváth R. \& HaAs J. 2014: A Dachsteini Mészkő szedimentológiai jellegei és képződésének körülményei a Budai-hegységben. — Földtani Közlöny 144/1, 143-154.

House, C. H., Runnegar, B. \& Fitz GibBon, S. T. 2003: Geobiological analysis using whole genome based tree building applied to the Bacteria, Archaea, and Eukarya. — Geobiology 1/1, 15-26. https://doi.org/10.1046/j.1472-4669.2003.00004.X

Humblet, M., Potts, D. C., Webster, J. M., Braga, J. C., Iryu, Y., Yokoyama, Y., Bourillot, R., SÉard, C., Droxler, A. \& Fujita, K. 2019: Late glacial to deglacial variation of coralgal assemblages in the Great Barrier Reef, Australia. — Global and Planetary Change 174, 70-91. https://doi.org/10.1016/j.gloplacha.2018.12.014

JAHNERT, R. J. \& Collins, L. B. 2013: Controls on microbial activity and tidal flat evolution in Shark Bay, Western Australia. Sedimentology 60/4, 1071-1099. https://doi.org/10.1111/sed.12023 
James, N. P. \& Gravestock, D. I. 1990: Lower Cambrian shelf and shelf margin buildups, Flinders Ranges, South Australia 1. — Sedimentology 37/3, 455-480. https://doi.org/10.1111/j.1365-3091.1990.tb00147.x

James, N. P., Ginsburg, R. N., Marszalek, D. S. \& Choquette, P. W. 1976: Facies and fabric specificity of early subsea cements in shallow Belize (British Honduras) reefs. — Journal of Sedimentary Research 46/3, 523-544. https://doi.org/10.1306/212F6FDC2B24-11D7-8648000102C1865D

Jones, B. \& HunTER, I. G. 1991: Corals to rhodolites to microbialites: a community replacement sequence indicative of regressive conditions. - Palaios 54-66. ttps://doi.org/10.2307/3514953

KALKOWSKY, E. 1908: Oolith und Stromatolith im norddeutschen Buntsandstein. —Zeitschrift der deutschen geologischen Gesellschaft 68-125.

Kandianis, M. T. 2007: Modeling Departures From Abiotic Expectations During the Calcium Carbonate Precipitation Process. University of Illinois at Urbana-Champaign.

KaZmierczaK, J. \& KemPE, S. 1992: Recent cyanobacterial counterparts of Paleozoic Wetheredella and related problematic fossils. Palaios 294-304. ttps://doi.org/10.2307/3514974

Kazmierczak, J., Coleman, M. L., Gruszczynski, M. \& Kempe, S. 1996: Cyanobacterial key to the genesis of micritic and peloidal limestones in ancient seas. - Acta Palaeontologica Polonica 41/4, 319-338.

Kele, S., Demény, A., Siklósy, Z., Németh, T., Tóth, M. \& Kovács, M. B. 2008: Chemical and stable isotope composition of recent hotwater travertines and associated thermal waters, from Egerszalók, Hungary: Depositional facies and non-equilibrium fractionation. — Sedimentary Geology 211/3-4, 53-72. https://doi.org/10.1016/j.sedgeo.2008.08.004

Kellerman, K. F. \& SMITH, N. R. 1914: Bacterial precipitation of calcium carbonate. — Journal of the Washington Academy of Sciences 4/14, 400-402.

Knoll, A. H. 2003: The geological consequences of evolution. - Geobiology 1/1, 3-14. https://doi.org/10.1046/j.1472-4669.2003. 00002.X

Knorre, H. \& Krumbein, W. E. 2000: Bacterial calcification. — In: Riding, R. \& AwramiK,S. M. (eds): Microbial Sediments 25-31. Heidelberg: Springer-Verlag.

Kolo, K., Konhauser, K., Prian, J.-P. \& PrÉAt, A. 2015: Probable fungal colonization and carbonate diagenesis of neoproterozoic stromatolites from South Gabon, Western Congo Basin. - In: DE Wit, M., Guillocheau, F. \& DE Wit, M. (eds): Geology and Resource Potential of the Congo Basin 77-96. Berlin, Heidelberg: Regional Geology Reviews. Springer.

Kovács S., Less Gy., Piros O., RéTi Zs. \& Róth L. 1993: Aggtelek-Rudabányai egység. — In: HaAs, J. (szerk.): Magyarország litosztratigráfiai alapegységei. Triász. 155-221. Budapest, A Magyar Állami Földtani alkalmi kiadványa.

KovÁcs S., Less Gy., HiPs K., PIros O. \& JózSA S. 2004: Aggteleki-rudabányai egységek. — In: HAAS, J. (szerk.): Magyarország geológiája. Triász. 197-288. Budapest, A Magyar Állami Földtani alkalmi kiadványa.

Krumbein, W. E. 1979: Calcification by bacteria and algae. — In: Trudinger, P. A. \& Swaine, D. J. (eds): Biogeochemical cycling of mineral-forming elements 3, 47-68 Elsevier Amsterdam.

Krumbein, W. E., Cohen, Y. \& Shilo, M. 1977: Solar Lake (Sinai). 4. Stromatolitic cyanobacterial mats. — Limnology and Oceanography 22/4, 635-656. https://doi.org/10.4319/lo.1977.22.4.0635

Krumbein, W. E., Brehm, U., Gerdes, G., Gorbushina, A. A., Levit, G. \& Palinska, K. A. 2003: Biofilm, biodictyon, biomat microbialites, oolites, stromatolites geophysiology, global mechanism, parahistology. — In: KrUMBEIN, W. E., PATERSON, D. M. \& ZaVArZin, G. A. (eds): Fossil and Recent biofilms 1-27. Dordrecht: Springer.

LALOU, C. 1957: Studies on bacterial precipitation of carbonates in sea water. — Journal of Sedimentary Research 27/2, https://doi.org/ 10.1306/74D706A0-2B21-11D7-8648000102C1865D

Lees, A. \& Miller, J. 1995: Waulsortian Banks. — In: Monty, C., Bosench, D., Bridges,P. \& Pratt, B. (eds): Mud Mounds. 23, 191271. IAS Special Publication.

LEINFELDER, R. R. \& SCHMID, D. U. 2000: Mesozoic reefal thrombolites and other microbolites. — In: RIDING, R. \& AwRAMIK, S. M. (eds): Microbial Sediments 289-294. Heidelberg: Springer-Verlag.

Logan, B. W. 1961: Cryptozoon and associate stromatolites from the recent, Shark Bay, Western Australia. — The Journal of Geology 69/5, 517-533. https://doi.org/10.1086/626769

LogAn, B. W., REZAK, R. \& GinsBURG, R. N. 1964: Classification and environmental significance of algal stromatolites. — The Journal of Geology 72/1, 68-83. https://doi.org/10.1086/626965

LowE, D. R. 1980: Stromatolites 3,400-myr old from the Archean of Western Australia. — Nature 284/5755, 441-443. https://doi.org/ $10.1038 / 284441 \mathrm{a} 0$

Lukoczki, G., HaAs, J., GregG, J. M., Machel, H. G., Kele, S. \& John, C. M. 2020: Early dolomitization and partial burial recrystallization: a case study of Middle Triassic peritidal dolomites in the Villány Hills (SW Hungary) using petrography, carbon, oxygen, strontium and clumped isotope data. - International Journal of Earth Sciences 109, 1051-1070. https://doi.org/10.1007/s00531-020-01851-7

Macintyre, I. G. \& Videtich, P. E. 1979: Pseudostalactites from Submarine Cave Near Columbus Cay, Belize Barrier-Reef ComplexEvidence of Extensive Submarine Lithification. — AAPG Bulletin 63/3, 489.

Macintyre, I. G., Mountjoy, E. W. \& D'Anglejan, B. F. 1968: An occurrence of submarine cementation of carbonate sediments off the west coast of Barbados, W. I. — Journal of Sedimentary Research 38/2, 660-664. https://doi.org/10.1306/74D71A19-2B21-11D7$8648000102 \mathrm{C} 1865 \mathrm{D}$

Macintyre, I. G., Prufert Bebout, L. \& Reid, R. P. 2000: The role of endolithic cyanobacteria in the formation of lithified laminae in Bahamian stromatolites. — Sedimentology 47/5, 915-921. https://doi.org/10.1046/j.1365-3091.2000.00327.x

Merz-Preiss, M. 2000: Calcification in cyanobacteria. - In: Riding, R. \& AwrAmik, S. M. (eds): Microbial Sediments 50-56. Heidelberg: Springer-Verlag Berlin. 
Merz, M. U. E. 1992: The biology of carbonate precipitation by cyanobacteria. — Facies 26/1, 81-101. https://doi.org/10.1007/ BF02539795

Montaggioni, L. F. \& Camoin, G. F. 1993: Stromatolites associated with coralgal communities in Holocene high-energy reefs. Geology 21/2, 149-152. https://doi.org/10.1130/0091-7613(1993)021<0149:SAWCCI>2.3.CO;2

Monty, C. L. V. 1965: Recent algal stromatolites in the windward lagoon, Andros Island, Bahamas. — Annales de la Société géologique de Belgique 88, 268-276.

Monty, C. L. V. 1967: Distribution and structure of recent stromatolitic algal mats, eastern Andros Island, Bahamas. — Annales de la Société géologique de Belgique 1966, 55-100.

Monty, C. L. V., Bosence, D. W. J., Bridges, P. H. \& Pratt, B. R. 1995: Carbonate Mud-Mounds: Their Origin and Evolution: Special Publication of the International Association of Sedimentologists, 23, Blackwell Science Ltd, Oxford.

MoritA, R. Y. 1980: Calcite precipitation by marine bacteria. — Geomicrobiology Journal 2/1, 63-82. https://doi.org/10.1080/ 01490458009377751

NAdson, G. A. 1928: Beitrag zur Kenntnis der bakteriogenen Kalkablagerungen. — In: ThIENEMAnN, A. U. G. (ed.): Archiv für Hydrobiologie, Organ der Interntionalen Verenigungfür Theoretische und Angewandte Limnologie. 19, 154-164 Stuttgart: E. Schweizerbart'sche Verlagsbuchhandlung.

Neumann, A. C., Gebelein, C. D. \& Scoffin, T. P. 1970: The composition, structure and erodability of subtidal mats, Abaco, Bahamas. — Journal of Sedimentary Research 40/1, 274-297. https://doi.org/10.1306/74D71F2D-2B21-11D7-8648000102C1865D

Neuweiler, F., Reitner, J., Monty, C., Feldmann, M., Awramik, S., Bourque, P.-A., Cirilli, S., Gautret, P., Marcoux, J. \& Plaziat, J. C. 1997: Biosedimentology of Microbial Buildups IGCP Project No. 380 Proceedings of 2nd Meeting, Göttingen/Germany 1996. —Facies 36/1, 195-284. https://doi.org/10.1007/BF02536885

Neuweiler, F., Rutsch, M., Geipel, G., Reimer, A. \& Heise, K.-H. 2000: Soluble humic substances from in situ precipitated microcrystalline calcium carbonate, internal sediment, and spar cement in a Cretaceous carbonate mud-mound. - Geology 28/9, 851-854. https://doi.org/10.1130/0091-7613(2000)28<851:SHSFIS >2.0.CO;2

Neuweiler, F., D’Orazio, V., Immenhauser, A., Geipel, G., Heise, K.-H., Cocozza, C. \& Miano, T. M. 2003: Fulvic acid-like organic compounds control nucleation of marine calcite under suboxic conditions. - Geology 31/8, 681-684. https://doi.org/10.1130/ G19775.1.

Nutman, A. P., Bennett, V. C., Friend, C. R. L., Van Kranendonk, M. J. \& Chivas, A. R. 2016: Rapid emergence of life shown by discovery of 3,700-million-year-old microbial structures. — Nature 537/7621, 535-538. https://doi.org/10.1038/nature19355

O'Toole, G., KaPlan, H. B. \& Kolter, R. 2000: Biofilm formation as microbial development. — Annual Reviews in Microbiology 54/1, 49-79. https://doi.org/10.1146/annurev.micro.54.1.49

OREN, A. \& TindALL, B. J. 2005: Nomenclature of the cyanophyta/cyanobacteria/cyanoprokaryotes under the International Code of Nomenclature of Prokaryotes. — Algological Studies 117/1, 39-52. https://doi.org/10.1127/1864-1318/2005/0117-0039

Paull, C. K., Chanton, J. P., Neumann, A. C., Coston, J. A., Martens, C. S. \& Showers, W. 1992: Indicators of methane-derived carbonates and chemosynthetic organic carbon deposits: examples from the Florida Escarpment. — Palaios 361-375. https://doi.org/ $10.2307 / 3514822$

Peckmann, J., Thiel, V., Michaelis, W., Clari, P., Gaillard, C., Martire, L. \& Reitner, J. 1999: Cold seep deposits of Beauvoisin (Oxfordian; southeastern France) and Marmorito (Miocene; northern Italy): microbially induced authigenic carbonates. International Journal of Earth Sciences 88/1, 60-75. https://doi.org/10.1007/s005310050246

Pentecost, A. 1985: Association of cyanobacteria with tufa deposits: identity, enumeration, and nature of the sheath material revealed by histochemistry. — Geomicrobiology Journal 4/3, 285-298. https://doi.org/10.1080/01490458509385936

Pentecost, A. \& Riding, R. 1986: Calcification in cyanobacteria. — In: Leadbeater, S. C. \& Riding, R. (eds): Biomineralization in lower plants and animals, 30, 73-90 Systematics Association.

Perry, C. T. \& Hepburn, L. J. 2008: Syn-depositional alteration of coral reef framework through bioerosion, encrustation and cementation: taphonomic signatures of reef accretion and reef depositional events. - Earth-Science Reviews 86/1-4, 106-144. https://doi.org/10.1016/j.earscirev.2007.08.006

PIA, J. 1926: Pflanzen als Gesteinsbildner. - Berlin, Gebruder Borntraeger.

PIROs, O. 2002: Anisian to Carnian carbonate platform facies and dasycladacean biostratigraphy of the Aggtelek Mts, Northeastern Hungary. - Acta Geologica Hungarica 45/2, 119-151.

Portman, C., Andrews, J. E., Rowe, P. J., LeEder, M. R. \& HoogewerfF, J. 2005: Submarine spring controlled calcification and growth of large Rivularia bioherms, Late Pleistocene (MIS 5e), Gulf of Corinth, Greece. - Sedimentology 52/3, 441-465. https://doi.org/ 10.1111/j.1365-3091.2005.00704.x

PRATT, B. R. 1982: Stromatolitic framework of carbonate mud-mounds. - Journal of Sedimentary Research 52/4, $1203-1227$. https://doi.org/10.1306/212F80FD-2B24-11D7-8648000102C1865D

PRATT, B. R. 1984: Epiphyton and Renalcis; diagenetic microfossils from calcification of coccoid blue-green algae. - Journal of Sedimentary Research 54/3, 948-971. https://doi.org/10.1306/212F853F-2B24-11D7-8648000102C1865D

RADWAŃSKY, A. \& SZULCZEWSKI, M. 1965: Stromatolitok a Villányi-hegység jura rétegeiben. — Földtani Közlöny 95/4, 418-422.

RAdWAŃsky, A. \& Szulczewski, M. 1966: Jurassic stromatolithes of the Villány Mountains (Southern Hungary). — Annales Universitatis Scientiarum Budapestinensis de Rolando Eötvös nominatae, Sectio Geologica 9 (1965) 87-107.

REITNER, J. 1993: Modern cryptic microbialite/metazoan facies from Lizard Island (Great Barrier Reef, Australia) formation and concepts. — Facies 29/1, 3-39. https://doi.org/10.1007/BF02536915

Reitner, J., Gautret, P., Marin, F. \& Neuweiler, F. 1995: Automicrites in a modern microbialite-Formation model via organic matrices (Lizard Island, Great Barrier Reef, Australia). - Bull. Inst. oceanogr. Monaco, num. spec 14, 1-26. 
Reitner, J., Thiel, V., Zankl, H., Michaelis, W., Wörheide, G. \& GaUtret, P. 2000: Organic and biogeochemical patterns in cryptic microbialites. - In: Riding, R. \& AwrAmiK, S. M. (eds): Microbial Sediments 149-160. Berlin, Heidelberg: Springer.

Reitner, J., Peckmann, J., Blumenberg, M., Michaelis, W., Reimer, A. \& Thiel, V. 2005: Concretionary methane-seep carbonates and associated microbial communities in Black Sea sediments. - Palaeogeography, Palaeoclimatology, Palaeoecology 227/1-3, 18-30. https://doi.org/10.1016/j.palaeo.2005.04.033

RIDING, R. 1991a: Calcified Cyanobacteria. - In: Riding, R. (ed.): Calcareous Algae and Stromatolites 55-87. Berlin, Heidelberg: Springer.

RIDING, R. 1991b: Classification of microbial carbonates. — In: RIDING, R. (ed.): Calcareous Algae and Stromatolites 21-51. Berlin: Springer.

RiDING, R. 1999: The term stromatolite: towards an essential definition. - Lethaia 32/4, 321-330. https://doi.org/10.1111/j.15023931.1999.tb00550.x

RIDING, R. 2000: Microbial carbonates: the geological record of calcified bacterial-algal mats and biofilms. — Sedimentology 47, 179 214. https://doi.org/10.1046/j.1365-3091.2000.00003.x

RIDING, R. 2002: Structure and composition of organic reefs and carbonate mud mounds: concepts and categories. - Earth-Science Reviews 58/1-2, 163-231. https://doi.org/10.1016/S0012-8252(01)00089-7

RIDING, R. 2006: Cyanobacterial calcification, carbon dioxide concentrating mechanisms, and Proterozoic-Cambrian changes in atmospheric composition. — Geobiology 4/4, 299-316. https://doi.org/10.1111/j.1472-4669.2006.00087.x

Riding, R. 2011: Reefal microbial crusts. — In: Hopley, D. (ed.): Encyclopedia of Modern Coral Reefs: Structure, Form and Process 911-915. Dordrecht: Encyclopedia of Earth Science Series, Springer.

Riding, R. \& AwRAmiK, S. M. 2000: Microbial Sediments. - Heidelberg: Springer-Verlag Berlin.

RidinG, R. \& LIANG, L. 2005: Geobiology of microbial carbonates: metazoan and seawater saturation state influences on secular trends during the Phanerozoic. - Palaeogeography, Palaeoclimatology, Palaeoecology 219/1-2, 101-115. https://doi.org/10.1016/j.palaeo.2004.11.018

Riding, R. \& SHARMA, M. 1998: Late Palaeoproterozoic ( 1800-1600 Ma) stromatolites, Cuddapah Basin, southern India: cyanobacterial or other bacterial microfabrics? — Precambrian Research 92/1, 21-35. https://doi.org/10.1016/S0301-9268(98)00065-5

RIDING, R. \& TomÁs, S. 2006: Stromatolite reef crusts, Early Cretaceous, Spain: bacterial origin of in situ precipitated peloid microspar? — Sedimentology 53/1, 23-34. https://doi.org/10.1111/j.1365-3091.2005.00751.x

Riding, R., Awramik, S. M., Winsborough, B. M., Griffin, K. M. \& Dill, R. F. 1991: Bahamian giant stromatolites: microbial composition of surface mats. — Geological Magazine 128/3, 227-234. https://doi.org/10.1017/S001675680002207X

Riding, R., LiAnG, L. \& BRAGA, J. C. 2014: Millennial scale ocean acidification and late Quaternary decline of cryptic bacterial crusts in tropical reefs. — Geobiology 12/5, 387-405. https://doi.org/10.1111/gbi.12097

RisgaARd-Petersen, N., Revil, A., Meister, P. \& Nielsen, L. P. 2012: Sulfur, iron-, and calcium cycling associated with natural electric currents running through marine sediment. — Geochimica et Cosmochimica Acta 92, 1-13. https://doi.org/10.1016/j.gca.2012.05. 036

Rivadeneyra, M. A., Ramos-Cormenzana, A. \& García-Cervigón, A. 1985: Étude de l'influence du rapport Mg/Ca sur la formation de carbonate par des bactéries telluriques. — Canadian Journal of Microbiology 31/3, 229-231. https://doi.org/10.1139/m85-044

Rivadeneyra, M. A., Delgado, R., Del Moral, A., Ferrer, M. R. \& Ramos-Cormenzana, A. 1994: Precipatation of calcium carbonate by Vibrio spp. from an inland saltern. — FEMS Microbiology Ecology 13/3, 197-204. https://doi.org/10.1111/j.1574-6941.1994.tb00066.x

Schlager, W. 2003: Benthic carbonate factories of the Phanerozoic. — International Journal of Earth Sciences 92/4, 445-464. https://doi.org/10.1007/s00531-003-0327-x

SCHMITTNER, K. E. \& GIRESSE, P. 1999: Micro environmental controls on biomineralization: superficial processes of apatite and calcite precipitation in Quaternary soils, Roussillon, France. — Sedimentology 46/3, 463-476. https://doi.org/10.1046/j.1365-3091.1999.00224.x

SCHROEDER, J. H. 1972: Calcified filaments of an endolithic alga in Recent Bermuda reefs. — Neues Jahrbuch für Geologie und Paläontologie Monatshefte 1, 16-33.

Seard, C., Camoin, G., Yokoyama, Y., Matsuzaki, H., Durand, N., Bard, E., Sepulcre, S. \& Deschamps, P. 2011: Microbialite development patterns in the last deglacial reefs from Tahiti (French Polynesia; IODP Expedition 310): Implications on reef framework architecture. — Marine Geology 279/1-4, 63-86. https://doi.org/10.1016/j.margeo.2010.10.013

Seckbach, J. \& OREn, A. 2010: Microbial mats: Modern and Ancient Microorganisms in Stratified Systems 14, - Springer Science+Business Media B.V.

ShAPIRO, R. S. 2000: A comment on the systematic confusion of thrombolites. — Palaios 15/2, 166-169. https://doi.org/10.1669/08831351(2000)015<0166:ACOTSC >2.0.CO;2

Shixing, Z. \& HuIneng, C. 1992: Characteristics of Palaeoproterozoic stromatolites in China. — Precambrian Research 57/1-2, 135163. https://doi.org/10.1016/0301-9268(92)90097-8

StePhens, N. P. \& Sumner, D. Y. 2002: Renalcids as fossilized biofilm clusters. — Palaios 17/3, 225-236. https://doi.org/10.1669/08831351(2002)017<0225:RAFBC>2.0.CO;2

Stockman, K. W., Ginsburg, R. N. \& Shinn, E. A. 1967: The production of lime mud by algae in south Florida. - Journal of Sedimentary Research 37/2, 633-648. https://doi.org/10.1306/74D7173A-2B21-11D7-8648000102C1865D

Stolz, J. F. 2000: Structure of microbial mats and biofilms. — In: Riding, R. \& AwramiK, S. M. (eds): Microbial Sediments 1-8. Heidelberg: Springer-Verlag Berlin.

Stolz, J. F. 2017: Gaia and her microbiome. - FEMS Microbiology Ecology 93/2, fiw247. https://doi.org/10.1093/femsec/fiw247

Stumm, W. \& Morgan, J. J. 1996: Chemical equilibria and rates in natural waters. — Aquatic Chemistry 1022.

Summons, R. E. 2004: Lipids, biomarkers and the history of life. — Microbiology Australia 25/1, 32-33. https://doi.org/10.1071/ MA04132 
Szilágyi, Z., Webster, J. M., Patterson, M. A., Hips, K., Riding, R., Foley, M., Humblet, M., Yokoyama, Y., Liang, L., Gischler, E., Montaggioni, L., GHerardi, D. \& Braga, J. C. 2020: Controls on the spatio-temporal distribution of microbialite crusts on the Great Barrier Reef over the past 30,000 years. - Marine Geology 429, 106312, https://doi.org/10.1016/j.margeo.2020.106312

Szives, O., Csontos, L., Bujtor, L. \& Fốzy, I. 2007: Aptian-Campanian ammonites of Hungary. — Geologica Hungarica series Palaeontologica 57, Magyar Állami Földtani Intézet.

TEWARI, V. \& SECKBACH, J. 2011: Stromatolites: interaction of microbes with sediments 18 - Springer Science+Business Media B.V.

Thiel, V., Merz-Preiss, M., Reitner, J. \& Michaelis, W. 1997: Biomarker studies on microbial carbonates: extractable lipids of a calcifying cyanobacterial mat (Everglades, USA). — Facies 36/1, 163-172. https://doi.org/10.1007/BF02536882

TöRÖK, Á. 1997: Triassic ramp evolution in Southern Hungary and its similarities to the Germano-type Triassic. — Acta Geologica Hungarica 40/4, 367-390.

TöRÖк, Á. 1998: Controls on development of Mid-Triassic ramps: examples from southern Hungary. — Geological Society, London, Special Publications 149/1,339-367. https://doi.org/10.1144/GSL.SP.1999.149.01.16

TöröK, Á., Mindszenty, A., Claes, H., Kele, S., Fodor, L. \& Swennen, R. 2017: Geobody architecture of continental carbonates: "Gazda" travertine quarry (Süttő, Gerecse Hills, Hungary). — Quaternary International 437, 164-185. https://doi.org/ 10.1016/j.quaint.2016.09.030

Trichet, J. \& DeFARge, C. 1995: Non-biologically supported organomineralization. — Bulletin de l'Institut Océanographique de Monaco, Numero Special 203-236.

Trichet, J., DeFarge, C., Tribble, J., Tribble, G. \& Sansone, F. 2001: Christmas Island lagoonal lakes, models for the deposition of carbonate-evaporite-organic laminated sediments. — Sedimentary Geology 140/1-2, 177-189. https://doi.org/10.1016/S00370738(00)00177-9

Turner, E. C., James, N. P. \& Narbonne, G. M. 2000: Taphonomic control on microstructure in Early Neoproterozoic reefal stromatolites and thrombolites. — Palaios 15/2, 87-111. https://doi.org/10.1669/0883-1351(2000)015<0087:TCOMIE>2.0.CO;2

Vargas, M. A., Rodriguez, H., Moreno, J., Olivares, H., Del Campo, J. A., Rivas, J. \& Guerrero, M. G. 1998: Biochemical composition and fatty acid content of filamentous nitrogen fixing cyanobacteria. - Journal of Phycology 34/5, 812-817. https://doi.org/10.1046/j.1529-8817.1998.340812.x

Velledits F., Bércziné MaKK A. \& Piros O. 1999: A Kisfennsíki Mészkő (Bükk hegység) fáciese és kora. — Földtani Közlöny 129, 573-592.

Velledits F., Pelikán P., Hips K., Harangi S., HaAs J., Józsa S. \& Kovács S. 2004: Bükki egység. — In: HaAs, J. (szerk.): Magyarország geológiája. Triász. 139-196. ELTE Eötvös Kiadó.

Verrecchia, E. P., Loisy, C., Braissant, O. \& Gorbushina, A. A. 2003: The Role of Fungal Biofilm and Networks in the Terrestrial Calcium Carbonate Cycle. - In: Krumbein, W. E., Paterson, D. M. \& Zavarzin, G. A. (eds): Fossil and Recent Biofilms 363-369. Dordrecht, Springer.

VISSCHER, P. T. \& STOLZ, J. F. 2005: Microbial mats as bioreactors: populations, processes, and products. — In: Geobiology: Objectives, Concepts, Perspectives 87-100. Elsevier.

Visscher, P. T., ReID, R. P. \& Bebout, B. M. 2000: Microscale observations of sulfate reduction: correlation of microbial activity with lithified micritic laminae in modern marine stromatolites. — Geology 28/10, 919-922. https://doi.org/10.1130/0091-7613(2000)028 $<0919$ :MOOSRC>2.3.CO;2

VöRös A. 1972: A Villányi-hegység alsó- és középső-jura képződményeinek üledékföldtani vizsgálata. —Földtani Közlöny 102, 12-28.

VöRös A. 2010: A villányi mezozoos rétegsor: visszatekintés új nézőpontból. — Földtani Közlöny 140/1, 3-30.

VöRöS, A. \& GALÁCZ, A. 1998: Jurassic palaeogeography of the Transdanubian Central Range (Hungary). — Rivista Italiana di Paleontologia e Stratigrafia 104/1.

WALTER, M. R. (ed.) 1976: Stromatolites. — Elsevier, 789 p.

WebB, G. E. 1996: Was Phanerozoic reef history controlled by the distribution of non enzymatically secreted reef carbonates (microbial carbonate and biologically induced cement)? — Sedimentology 43/6, 947-971. https://doi.org/10.1111/j.1365-3091.1996.tb01513.x

WebB, G. E. \& Kamber, B. S. 2000: Rare earth elements in Holocene reefal microbialites: a new shallow seawater proxy. — Geochimica et Cosmochimica Acta 64/9, 1557-1565. https://doi.org/10.1016/S0016-7037(99)00400-7

WebB, G. E. \& Kamber, B. S. 2004: Biogenicity inferred from microbialite geochemistry. — Microbiology Australia 25/1, 34-35. https://doi.org/10.1071/MA04134

WebB, G. E., JeLl, J. S. \& BAKER, J. C. 1999: Cryptic intertidal microbialites in beachrock, Heron Island, Great Barrier Reef: implications for the origin of microcrystalline beachrock cement. - Sedimentary Geology 126/1-4, 317-334. https://doi.org/10.1016/S00370738(99)00047-0

Webster, J. M., Yokoyama, Y. \& Cotterill, C. 2011: Proceedings of the Integrated Ocean Drilling Program Volume 325 Expedition Reports Great Barrier Reef Environmental Changes. https://doi.org/10.2204/iodp.proc.325.2011

Webster, J. M., Braga, J. C., Humblet, M., Potts, D. C., Iryu, Y., Yokoyama, Y., Fujita, K., Bourillot, R., Esat, T. M. \& Fallon, S. 2018: Response of the Great Barrier Reef to sea-level and environmental changes over the past 30,000 years. — Nature Geoscience 11/6, 426. https://doi.org/10.1038/s41561-018-0127-3

Westbroek, P., Buddemeier, B., Coleman, M., KoK, D. J. \& Fautin, D. 1994: Strategies for the study of climate forcing by calcification. - Bulletin de l'Institut Océanographique de Monaco 37-60.

WooD, R. 2001: Are reefs and mud mounds really so different? — Sedimentary Geology 145/3-4, 161-171. https://doi.org/10.1016/ S0037-0738(01)00146-4

Wright, P. \& RoDRIGUEZ, K. 2018: Reinterpreting the South Atlantic pre-salt 'microbialite' reservoirs: Petrographic, isotopic and seismic evidence for a shallow evaporitic lake depositional model. — First Break 36/5, 71-77. https://doi.org/10.3997/1365-2397.n0094 
XIE, S. \& Kershaw, S. 2012: Microbes and paleoenvironments. — Geobiology 10/1, 1-2. https://doi.org/10.1111/j.1472-4669.2011. 00311.X

Yokoyama, Y., Webster, J. M., Cotterill, C., Braga, J. C., Jovane, L., Mills, H., Morgan, S. \& Suzuki, A. 2011: IODP Expedition 325: Great Barrier Reefs Reveals Past Sea-Level, Climate and Environmental Changes Since the Last Ice Age. — Scientific Drilling 12. https://doi.org/10.2204/iodp.sd.12.04.2011

Yokoyama, Y., Esat, T. M., Thompson, W. G., Thomas, A. L., Webster, J. M., Miyairi, Y., Sawada, C., Aze, T., Matsuzaki, H. \& OKuno, J. 2018: Rapid glaciation and a two-step sea level plunge into the Last Glacial Maximum. — Nature 559/7715, 603-607. https://doi.org/10.1038/s41586-018-0335-4

ZAVARZIN, G. A. 2002: Microbial geochemical calcium cycle. — Microbiology 71/1, 1-17. https://doi.org/10.1023/A:1017945329951

Zhou, K. \& Pratt, B. R. 2019: Composition and origin of stromatactis bearing mud mounds (Upper Devonian, Frasnian), southern Rocky Mountains, western Canada. — Sedimentology 66/6, 2455-2489. https://doi.org/10.1111/sed.12595

Kézirat beérkezett:2020. 07. 09. 